\title{
Leveraging Nuclear Receptors as Targets for Pathological Ocular Vascular Diseases
}

\author{
Pei-Li Yao ${ }^{1,+}$, Jeremy Peavey ${ }^{1,+}\left(\mathbb{D}\right.$ and Goldis Malek ${ }^{1,2, *}$ \\ 1 Duke Eye Center, Department of Ophthalmology, Duke University School of Medicine, Durham, NC 27503, \\ USA; Peili.yao@duke.edu (P.-L.Y.); jeremy.peavey@duke.edu (J.P.) \\ 2 Department of Pathology, Duke University School of Medicine, Durham, NC 27503, USA \\ * Correspondence: gmalek@duke.edu; Tel.: +919-684-0820 \\ + These authors contributed equally to this work.
}

Received: 21 March 2020; Accepted: 19 April 2020; Published: 21 April 2020

\begin{abstract}
Vasculogenesis and angiogenesis are physiological mechanisms occurring throughout the body. Any disruption to the precise balance of blood vessel growth necessary to support healthy tissue, and the inhibition of abnormal vessel sprouting has the potential to negatively impact stages of development and/or healing. Therefore, the identification of key regulators of these vascular processes is critical to identifying therapeutic means by which to target vascular-associated compromises and complications. Nuclear receptors are a family of transcription factors that have been shown to be involved in modulating different aspects of vascular biology in many tissues systems. Most recently, the role of nuclear receptors in ocular biology and vasculopathies has garnered interest. Herein, we review studies that have used in vitro assays and in vivo models to investigate nuclear receptor-driven pathways in two ocular vascular diseases associated with blindness, wet or exudative age-related macular degeneration, and proliferative diabetic retinopathy. The potential therapeutic targeting of nuclear receptors for ocular diseases is also discussed.
\end{abstract}

Keywords: nuclear receptors; angiogenesis; wet age-related macular degeneration; proliferative diabetic retinopathy; inflammation

\section{Introduction}

The formation of vascular networks is an essential mechanism that occurs throughout the body and one that has been studied extensively not only in the course of development but also during the initiation and progression of degenerative diseases [1]. As such, it plays an important role in promoting and/or limiting the impact of the inflammatory response [2]. The field of vascular biology often refers to 'angiogenesis' as the sprouting of endothelial cells from an existing vascular tree resulting in new vessel formation [3], while 'vasculogenesis' denotes new vessel formation during embryonic development. 'Vasculogenesis' also occurs in adults and involves the revascularization or neovascularization of damaged tissue. In the ocular field, neovascularization denotes the latter process and occurs in vision debilitating retinal diseases including but not limited to the wet form of age-related macular degeneration and proliferative diabetic retinopathy. Regardless of the blood vessel formation mechanism, key events that occur in vascular development include activation, migration, proliferation, and the maturation of precursor cells [4]. Critical regulators of vascular processes are actively under investigation and are considered important therapeutic targets for vascular diseases. One set of regulators of vascular biology and physiology are a family of transcription factors called nuclear receptors, which have been shown to play an important role during development, aging, and diseases characterized by vascular structure and function abnormalities [5]. The goal of this review is to discuss the potential role of nuclear receptors in ocular vascular diseases of the posterior pole, 
specifically wet age-related macular degeneration and diabetic retinopathy, which are two leading causes of vision impairment in the elderly and working class populations, respectively.

\section{Role of Nuclear Receptors in Angiogenesis}

Nuclear receptors (NR) are the largest family of transcription factors in the human genome. Since their discovery in 1988, they have been studied extensively not only in endocrine organs but also in almost all other tissue types within the body [6]. The NR superfamily is comprised of 48 members, and it is functionally diverse. A myriad of mechanisms of action have been linked to the different NRs during normal development, reproduction, and aging as well as the pathology of a number of human neurodegenerative and systemic diseases. Given the importance of blood vessel formation in health and disease, the functions of NRs in angiogenesis and vasculogenesis have also received much attention, in particular in the field of cancer biology [7-10]. The role of vascular biology in ocular diseases has also stimulated an interest in investigating NRs during ocular development and ocular vascular diseases. Herein, we will focus on a number of seminal studies that have launched an ever-growing interest in understanding the contributions of NRs to ocular angiogenesis and vasculogenesis and in particular the goal of harnessing the power of targeting NRs for potential therapy.

\section{Nuclear Receptor Signaling in the Pathogenesis of Age-Related Macular Degeneration}

\subsection{Overview of Age-Related Macular Degeneration}

Age-related macular degeneration (AMD), a leading cause of central vision loss in the elderly, is characterized by the accumulation of lipid- and protein-rich deposits between the retinal pigment epithelial (RPE) cells and Bruch's membrane [11,12]. The advanced clinical sub-types of AMD are differentiated as dry (late dry AMD or geographic atrophy-GA) or exudative (wet AMD) and distinguished by the absence and presence of blood vessels invading from the choroid into the subretinal space, respectively. Clinically, approximately $85 \%$ of AMD patients are diagnosed with GA. These patients experience vision loss in the central macula and morphologically present with widespread RPE cell death along with significance photoreceptor loss. Meanwhile, the approximately $10 \%$ of patients diagnosed with wet AMD experience choroidal neovascularization (CNV), where immature blood vessels in the choroid expand below the RPE cell layer and often toward the outer retina, resulting in plasma exudation and hemorrhage. Late wet AMD can further evolve into fibrotic scaring, RPE detachment, and acute blindness (Figure 1).

\subsection{Molecular Mechanisms and Etiology of AMD}

AMD is a progressive macular degenerative disease with complex and heterogeneous features. The progression of AMD is highly variable among individuals. We and others have previously reviewed some of the signaling pathways implicated in the pathogenesis of AMD along with potential risk factors for developing the disease [12-16]. The biological pathways identified to date include but are not limited to inflammation, oxidative stress, lipid dysregulation, and vascular compromise. These in combination with genetic risk, environmental factors, and overall health conditions further underscore the complexity of AMD (Figure 2). Likewise, functional vision in the posterior segment relies on multiple cell types, including RPE cells, photoreceptors, choroidal endothelial cells, macrophages, and microglia. Thus, it is credible that the dysfunction of some or all of these cells and/or an imbalance in cellular communication may promote AMD advancement. With this in mind, the priority for developing new therapies relies on further realizing the underlying mechanisms of the disease and identifying targetable signaling pathways. 

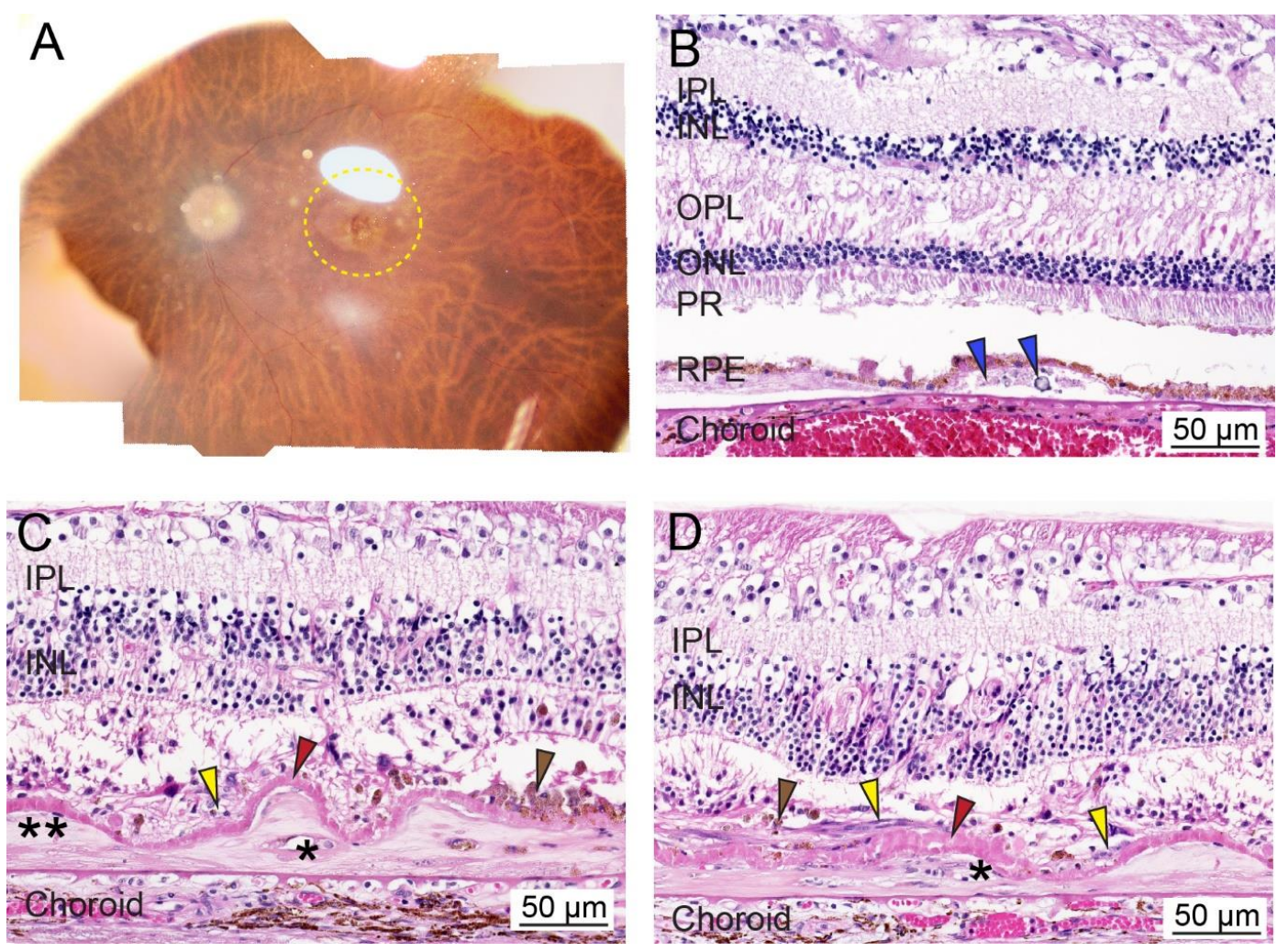

Figure 1. Ex vivo whole tissue and cross-sectional histopathology of human age-related macular degeneration (AMD). (A) Representative post-mortem fundus image of an eye from an AMD patient with early dry AMD (OD; 90-year-old male; death to recovery: $7 \mathrm{~h} 19 \mathrm{~min}$; cause of death: congestive heart failure). The area with AMD lesions is delineated with a yellow dotted line. (B) Representative histopathology of paraformaldehyde-fixed paraffin-embedded cross-sections of the retina stained with hematoxylin and eosin from a patient with dry AMD phenotypes (OD; 100-year-old female; death to recovery: unknown; cause of death: unknown). Blue arrowhead: lipid- and protein-rich deposits or drusen within the sub-RPE region. (C,D) Representative histopathology of paraformaldehyde-fixed paraffin-embedded cross-sections of the retina stained with hematoxylin and eosin from a patient with glaucoma and wet AMD (OD; 103-year-old female; death to recovery: unknown; cause of death: unknown). Severe photoreceptor degeneration, along with two-component fibrocellular disciform scars and a thickened intra-Bruch's membrane component (two asterisks) and the thin subretinal component (yellow arrowheads). Thin subretinal pigment epithelial fibrovascular membranes (asterisks) are present in disciform scars (two asterisks). A layer of basal laminar deposit (red arrowheads) is located between the disciform scar (yellow arrowheads) and Bruch's membrane. Brown arrowhead; cluster of pigmented cells. IPL, inner plexiform layer; INL, inner nuclear layer; OPL, outer plexiform layer; ONL, outer nuclear layer; PR, photoreceptor; RPE, retinal pigment epithelium. Bar $=50 \mu \mathrm{m}$.

AMD patients with $\mathrm{CNV}$, which tend to develop severe vision loss, typically exhibit increased angiogenesis and neovascularization in the choroid with hemorrhage and fluid accumulation in the subretinal space, ultimately involving the retinal vasculature in the case of retinal angiomatous proliferation. These phenotypic changes may be the result of imbalanced vascular inflammation, impaired epithelial and/or endothelial cell migration and adhesion, abnormal cell proliferation, and/or dysregulated mitochondrial function $[17,18]$. Newly formed blood vessels recruit inflammatory cells which can produce inflammatory cytokines, chemokines, and growth factors responsible for promoting angiogenesis [19]. Although acute inflammation can serve as the immediate response against pathogenic infection, a chronic inflammatory condition tends to favor angiogenesis, leading to pathological complications of diseases, such as wet AMD. Whether or not the increased number of macrophages attracted to the retina and neovascular lesions indicates exacerbation of the disease 
or a repair process from the damage continues to be an area of intense investigation and likely will dependent upon the timing of the macrophage recruitment concomitant with the influence of adjacent resident cells within the microenvironment, such as RPE cells.

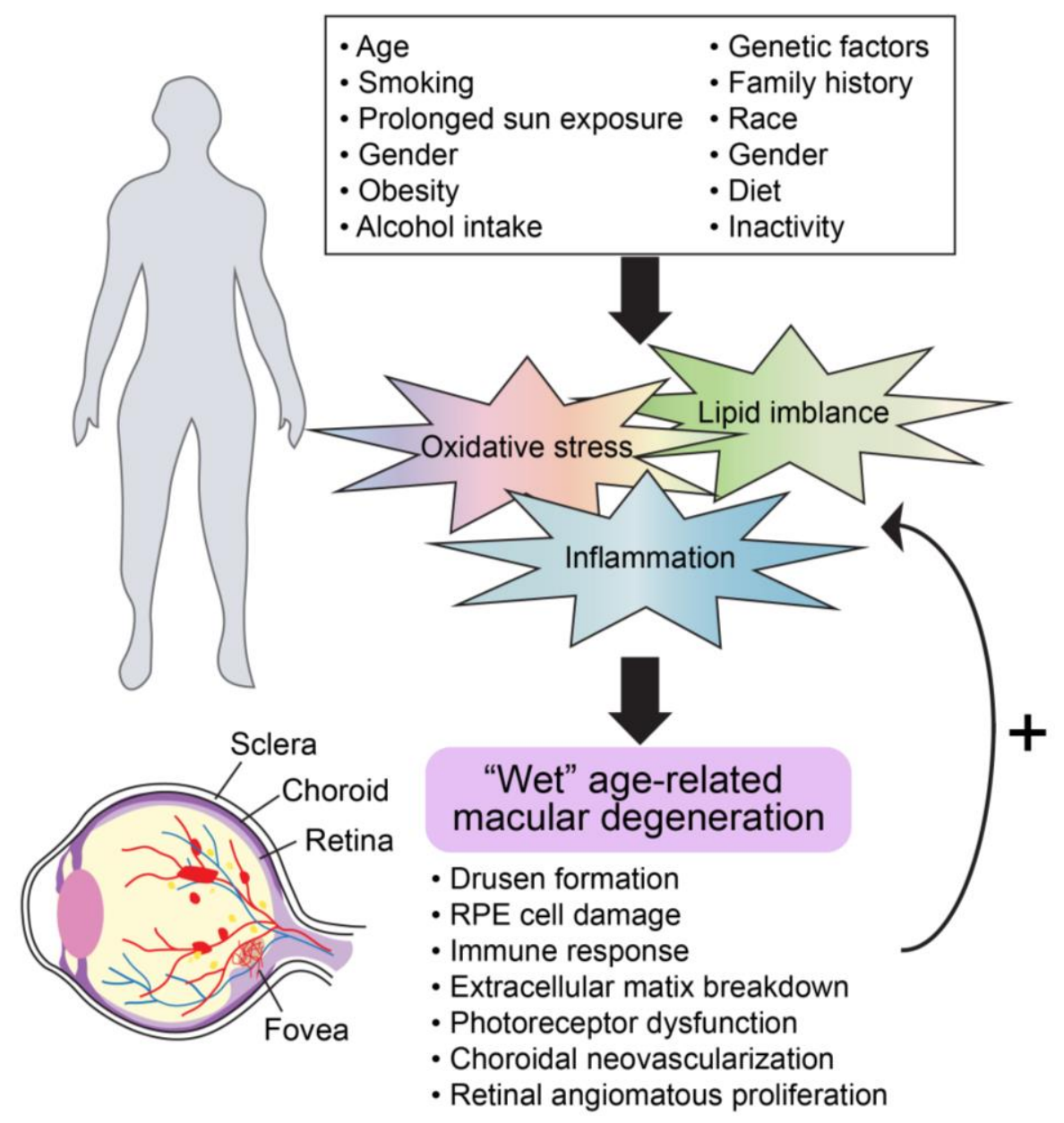

Figure 2. General molecular mechanisms involved in advanced AMD progression.

RPE cells play a central role in regulating CNV progression through their production/secretion of a number of angiogenic factors in response to environmental stimuli, including complement factors and growth factors such as vascular endothelial growth factor (VEGF). To date, targeting VEGF, a potent pro-angiogenic mediator, is still the standard treatment for neovascular AMD [20-22], and the efficacies of different anti-VEGF strategies have been extensively investigated. In general, VEGF-A stimulates the migration of endothelial cells and promotes vascular proliferation, required for angiogenesis under both physiological and pathological conditions. However, despite some success in vision improvement [23], an increasing number of body of studies have revealed unexpected complications of long term anti-VEGF-A therapy in treating ocular diseases. Human studies have shown altered retinal vascular immune cell homeostasis and RPE toxicity in a subset of patients [24,25], while mouse models in which VEGF is absent present with choriocapillary atrophy [26].

\subsection{Nuclear Receptors and AMD Pathobiology}

Nuclear receptors (NRs) have been shown to play a physiological role in RPE cells, which are susceptible to oxidative stress and inflammatory stimuli and of relevance; these are classified as 'AMD-vulnerable cells'. We previously established an NR atlas of human RPE cells [27], highlighting potential candidate receptors relevant to AMD pathogenesis. Increasing evidence is emerging 
to appreciate the functional participation of NRs in modulating ocular diseases through multiple mechanisms [16,28-30]. To date, the interest in finding links between NRs and wet AMD development and progression are still relatively new but growing. In the following sub-sections, we focus on recent studies illustrating the significance of specific nuclear receptors in wet AMD and, in particular, their contribution to regulation of angiogenesis using in vitro cell cultures and transgenic and/or experimentally induced laser CNV animal models.

\subsubsection{Peroxisome Proliferator-Activated Receptors (PPARs)}

PPARs are ligand-binding nuclear receptors that heterodimerize with their obligate binding partner, retinoid-x-receptors (RXRs), to regulate target gene expression levels through interactions with DNA response elements within specific promoter regions [31,32]. This family of nuclear receptors were first discovered in the early 1990s by researchers who noticed peroxisomal proliferation via treatment with rodent hepatocarcinogens [33]. The physiological importance of PPAR function is diffuse, and PPARs have demonstrated importance in a variety of diseases not limited to inflammatory, diabetic, cardiovascular, cancer, neurodegenerative, and ocular diseases [34]. They also control a variety of biological processes, including adipogenesis, cell proliferation and differentiation, lipid and glucose metabolism, inflammation, angiogenesis, and immune function [35]. Of relevance to ocular biology, PPAR isoforms (PPAR $\alpha$, PPAR $\beta / \delta$, and PPAR $\gamma$ ) are expressed in the choriocapillaris, choroidal endothelial cells, retinal endothelial cells, and RPE cells [36]. A series of recent works have linked a high dietary intake of omega-3 long-chain polyunsaturated fatty acids ( $\omega-3$ LCPUFAs), which are endogenous agonists of PPARs, with reduced ocular angiogenesis [37-42]. These studies demonstrate a protective role of activating PPARs against retinal diseases, including neovascular AMD.

In addition to its well-known function in lipid metabolism, PPAR $\alpha$ also has a critical role in inflammation. Similar to most NRs, whether PPAR $\alpha$ exhibits a pro- or anti-inflammatory effect is highly tissue- and cell-specific [35]. A recent study explored the effect of activating PPAR $\alpha$ on ocular neovascularization using laser-induced CNV rat and transgenic mouse models [43]. The systemic administration of fenofibric acid (Feno-FA), a potent PPAR $\alpha$ agonist, attenuated laser-induced CNV lesions and decreased inflammatory cytokine production. It is also worth noting that PPAR $\alpha^{-/-}$mice exhibit severe CNV features, and Feno-FA treatment has no effects on rescuing this phenotype [43].

In the $\mathrm{Ccl} 2^{-/-} / \mathrm{C} x 3 \mathrm{cr} 1^{-/-}$mice, a potential neovascular model, PPAR $\gamma$ expression is significantly increased [36], suggesting a conceivable role for PPAR $\gamma$ in AMD. The inhibitory effect of activating PPAR $\gamma$ by troglitazone or rosiglitazone on VEGF-induced proliferation and migration, VEGF-induced angiogenesis in vitro, and CNV lesions in vivo, using cultured cells (e.g., human RPE cells and bovine choroidal endothelial cells) and in rats, respectively, suggests that targeting PPAR $\gamma$ may be beneficial for treating neovascular AMD patients [44]. Mechanistically, the PPAR $\gamma$-dependent modulation of $\mathrm{CNV}$ progression may be attributable to PPAR $\gamma$ 's essential role in regulating the expression of genes associated with inflammatory and oxidative stress pathways [35,45].

Compared to PPAR $\alpha$ and PPAR $\gamma$, the biological roles of PPAR $\beta / \delta$ are considerably less defined. One potential mechanism of PPAR $\beta / \delta$ is that its activation may inhibit genetically or chemically induced inflammation in part by the reduced expression of cytokines through the trans-repression of NF-KB-dependent signaling [35]. On the other hand, the activation of PPAR $\beta / \delta$ may induce migration and angiogenesis in human endothelial cells, which is associated with the up-regulation of VEGF and matrix metalloproteinase 9 (MMP-9) [46]. With regard to AMD biology, $P P A R \beta / \delta$ is expressed in both RPE and choroidal endothelial cells [28], and aged PPAR $\beta / \delta^{-/-}$mice have been shown to develop several features of early dry AMD, including thin continuous sub-RPE deposits, Bruch's membrane thickening, RPE pigmentary changes, and disorganized basal infoldings in RPE cells, suggesting an essential role of PPAR $\beta / \delta$ in RPE cell health [28]. Importantly, knocking down PPAR $\beta / \delta$ expression or antagonizing PPAR $\beta / \delta$ activity has been shown to inhibit angiogenesis in vitro and attenuate the severity of laser-induced CNV lesions in vivo [28]. Thus, the functions of PPAR $\beta / \delta$ in pathogenic 
angiogenesis are most likely complicated, reflecting the need to consider cell-specific and selective modulation of PPAR $\beta / \delta$ in dry (receptor agonism) versus wet AMD (receptor antagonism).

\subsubsection{Liver $X$ Receptors (LXRs)}

Closely related to the PPAR subfamily, the LXRs act as cholesterol sensors, regulating glucose and cholesterol homeostasis [28], inflammation, and central nervous system development in response to endogenous and/or exogenous lipid ligands [47]. Transactivation and transrepression are the two genomic mechanisms that drive downstream LXR gene transcription. Transactivation involves the heterodimerization of LXR with RXR followed by binding to LXR response elements, the shedding of corepressors, and the recruitment of coactivators [48]. Transrepression requires the monomeric sumoylation of lysines in the ligand-binding domain of LXR to tether the monomer to a multimolecular corepressor complex [49], the molecular understanding of which is mildly understood. Both LXR isoforms, alpha and beta ( $L X R \alpha$ and $L X R \beta)$, are present in the retina, and their expression in human RPE-choroidal fractions decreases with age, which is the main risk factor of AMD [50,51]. LXR $\alpha^{-/}$ mice exhibit a progressive accumulation of neutral lipid rich extracellular deposits underneath the RPE, representing a typical early dry AMD phenotype [50]. Furthermore, aged $L X R \alpha^{-/-}$mice present with increased number of immune cells in the outer retina and elevated production of inflammatory cytokines within the RPE/choroid, which together reflect a pro-inflammatory response in the absence of $L X R \alpha$ [50]. In vitro, the ligand activation of LXR markedly suppresses the expression of inflammatory marker genes and attenuates intracellular lipid accumulation. The activation of LXR $\beta$ by a synthetic LXR ligand has been shown to protect the inner retinal damage against chemically-induced retinal degeneration. The protective role of LXR $\beta$ in ocular diseases is likely associated with the inhibited NF- $\mathrm{KB}$ signaling pathway and decreased amyloid- $\beta$ formation as evidence in $L X R \beta^{-/-}$mice $[51,52]$. Similarly, the activation of $\mathrm{LXR} \alpha$, in vivo, in the apoB-100 expressing mouse suppresses retinal inflammation and neutral lipid deposition in Bruch's membrane [50]. Finally, there is evidence for the role of LXRs in regulating ocular angiogenesis and CNV pathogenesis. This comes from not only a genome-wide microarray analysis study indicating that the early suppression of VEGF ligand-receptor signaling and inflammatory pathways associated with corneal angiogenesis is coupled with the activation of LXR/RXR, PPAR $\alpha / R X R \alpha$, and STAT3 pathways [53], but also in vivo studies in which treatment with an LXR agonist reduced the size and severity of laser induced CNV lesions in aged mice [54]. Given the fact that AMD patients often develop the dry form prior to neovascular AMD, dry AMD is considered a risk factor for developing wet AMD, and it is supposed that dry AMD treatments would also provide some protection against wet AMD [11].

\subsubsection{Estrogen Receptors (ERs)}

The sex steroid hormone estrogen and its receptor (estrogen receptor, ER) regulate diverse signaling pathways involved in cell differentiation, cell migration, survival, cell death, and synaptic responses in neurons. There is evidence of estrogen production in the eye, as both $E R \alpha$ and $E R \beta$ have been detected in the human retina [55], suggesting an ocular physiological role of ER signaling. Gender-focused studies have revealed significantly higher $\mathrm{CNV}$ scores in experimentally induced laser neovascular formation in females versus male rats in conjunction with elevated expressions of $E R \beta$ and the VEGF receptor 2 [56]. These studies are consistent with gender differences in the incidence of neovascular AMD $[57,58]$.

Changes in ER $\beta$ and VEGFR2 levels have also been observed in 17 $\beta$-estradiol (E2)-treated ovariectomized females. Similarly, estrogen exacerbating CNV formation also occurs in the laser-induced CNV mouse model in association with elevated TNF $\alpha$ expression and the activation of macrophages [59]. More recently, single nucleotide polymorphisms in the ER $\alpha$ and matrix metalloproteinase $2(M M P 2)$ genes have been shown to be associated with neovascular AMD and in particular in women $[60,61]$. Adverse effects of exogenous estrogen on wet AMD progression raises the concern of estrogen and its function in vision $[55,62]$. However, studies also suggest that hormone 
replacement therapy (HRT) and/or oral contraceptives may exhibit protective effects in women against neovascular AMD [62-64]. More studies are needed to clarify the relationship between estrogen and AMD in the context of aging. Case in point, a recent study reported CNV in young adult females after hormonal treatment for ovarian stimulation during fertility therapy [65], while hormone treatment and the use of oral contraceptives at postmenopausal age are associated with a lower risk of neovascular AMD [64].

\subsubsection{Aryl Hydrocarbon Receptor (AhR)}

Although not a traditional nuclear receptor, the aryl hydrocarbon receptor (AhR) also translocates to the nucleus upon ligand binding, interacts with the AhR nuclear translocator (ARNT) to form a heterodimer, and acts as transcriptional regulator to regulate xenobiotic metabolism, development, and carcinogenesis [66]. Previous studies have shown that the dysregulation of AhR fails to induce VEGF-dependent tube formation in human endothelial cells, and $A h R^{-/-}$mice exhibit impaired angiogenesis [67], which is indicative of a critical role of AhR in angiogenesis.

More recently, the differential regulation of AhR has been found to be associated with different AMD pathogeneses based on human RPE-choroid fractions subjected to high-throughput RNA sequencing [68]. Identified signaling pathways include inflammation, angiogenesis, and extracellular matrix regulation, supporting the functional significance of the AhR-mediated signaling pathway in AMD. We previously found that aged $A h R^{-/-}$mice spontaneously develop a dry AMD-like pathology, featuring thick sub-RPE deposit formation, disrupted RPE cell tight junctions, the accumulation of RPE cell lipofuscin, Bruch's membrane thickening, and RPE and choroidal atrophy [69]. Interestingly, in the absence of $A h R$, aged mice following laser-induced CNV develop lesions larger in area and volume compared to age-matched wild-type mice [68]. These lesions are also associated with typical characteristics observed in human wet AMD, including an increased number of ionized calcium-binding adaptor molecule 1-positive (Iba1)-positive microglial cells and enhanced collagen type IV deposition, which is consistent with in vitro findings that knocking-down $A h R$ increases the production of inflammatory cytokines and growth factors in RPE and choroidal endothelial cells. The activation of AhR by either leflunomide or flutamide significantly inhibits CNV formation in vitro and in vivo [70], demonstrating the therapeutic potential of targeting the AhR pathway in neovascular AMD. Thus, the differential regulation of $\mathrm{AhR}$ as either pro- or anti-angiogenic is cell- and tissue-dependent for nuclear receptors.

\subsubsection{Glucocorticoid Receptors (GR)}

Glucocorticoids are essential steroid hormones that bind to glucocorticoid receptors (GRs) to regulate metabolic homeostasis. The anti-inflammatory and immunosuppressive ability of glucocorticoids underlie their critical roles in a large number of human medical conditions, including ocular diseases [71-74]. Upon ligand binding, GRs undergo conformational changes, translocate into the nucleus, and act as transcription factors by directly regulating target gene expression or by indirectly interfering with other transcription factor-mediated signaling pathways [75]. A recent study has revealed an interaction between GR- and AhR-mediated signals in ARPE19 cells [76], pointing to a novel molecular mechanism in RPE biology and potentially AMD. Injections or implants of dexamethasone or triamcinolone acetanoid (TA), synthetic glucocorticoids, are commonly used in suppressing neovascularization in both laser-induced CNV animal models and human studies [71,77-79]. Recent studies also demonstrate the power of combination therapy using verteporfin (photodynamic therapy), glucocorticoids, and anti-VEGF agents in choroidal neovascularization [80-82]. The use of triple therapy not only improves the visual acuity of $\mathrm{CNV}$ patients, but it also reduces the frequency of repeating treatments. Anecortave acetate, a glucocorticoid analogue, has been shown to reduce choroidal neovascularization without affecting normal retinal angiogenesis [83-85]. Interestingly, anecortave acetate does not trigger GR-mediated signaling [86], indicating a unique mechanism of action of glucocorticoids. 


\subsection{Case Studies and Clinical Trials Examining the Relationship between Nuclear Receptors and AMD}

There are a limited number of case studies and clinical trials that have either been completed or are in progress, examining associations between various nuclear receptors and AMD (Table 1). It is notable that several nuclear receptors are currently FDA approved, which may facilitate faster testing in man should preclinical studies provide support for targeting said pathway in AMD.

Table 1. Case studies or clinical trials examining the relationships between nuclear receptors and wet AMD. CNV: choroidal neovascularization, GR: glucocorticoid receptor, ERs: estrogen receptors, PPAR: peroxisome proliferator-activated receptors, VEGF: vascular endothelial growth factor.

\begin{tabular}{|c|c|c|c|c|}
\hline Reference & Target & Type of Study & Cohort Size & Results and Interpretation \\
\hline Hong et al., 2018. Review [87] & PPARs & unknown & unknown & $\begin{array}{l}\text { PPAR } \alpha \text { agonist macuneos (Biophytis) is under clinical } \\
\text { trial phase I for treating AMD. }\end{array}$ \\
\hline $\begin{array}{l}\text { The Eye Disease Case-control } \\
\text { Study Group. } 1992 \text { [88] }\end{array}$ & ERs & Case-control study & $n=1036$ & $\begin{array}{l}\text { Women in the U.S. exposed to exogenous estrogen } \\
\text { exhibited lower risk of neovascular AMD. }\end{array}$ \\
\hline Snow et al., 2002 [64] & ERs & $\begin{array}{l}\text { Cross-sectional } \\
\text { study on } \\
\text { postmenopausal } \\
\text { women with AMD }\end{array}$ & $n=394$ & $\begin{array}{l}\text { Women under postmenopausal estrogen therapy } \\
\text { experienced lower grade of AMD. }\end{array}$ \\
\hline Tomany et al., 2004 [89] & ERs & $\begin{array}{l}\text { Population-based } \\
\text { cohort study } \\
\text { (meta-analysis) }\end{array}$ & $n=9523$ & $\begin{array}{l}\text { No significant associations between the use of hormone } \\
\text { therapy and the incidence of late AMD was reported. }\end{array}$ \\
\hline $\begin{array}{l}\text { Boekhoorn et al., 2007. The } \\
\text { Rotterdam Study [60] }\end{array}$ & ERs & $\begin{array}{l}\text { Population-based } \\
\text { cohort study }\end{array}$ & $n=4571$ & $\begin{array}{l}\text { ER } \alpha \text { polymorphisms (ESR1 PvuII-XbaI) are associated } \\
\text { with an increased incidence of wet AMD. }\end{array}$ \\
\hline Edwards et al., 2010 [63] & ERs & Case-control study & $n=799$ & $\begin{array}{l}\text { Hormone replacement therapy or oral contraceptives } \\
\text { have a protective role in women with neovascular AMD. }\end{array}$ \\
\hline Spaide et al., 2005 [90] & GRs & Small cohort study & $n=26$ & $\begin{array}{l}\text { CNV patients treated with combined photodynamic } \\
\text { therapy with verteporfin and intravitreal triamcinolone } \\
\text { acetonide (GR agonist) exhibited improved vision and } \\
\text { reduced treatment frequency. }\end{array}$ \\
\hline Augustin et al., 2007 [81] & GRs & Small cohort study & $n=104$ & $\begin{array}{l}\text { One cycle of triple therapy with verteporfin } \\
\text { (photodynamic therapy), dexamethasone (GR agonist), } \\
\text { and bevacizumab (anti-VEGF) improved the visual } \\
\text { acuity of CNV patients. }\end{array}$ \\
\hline Ehmann et al., 2010 [82] & GRs & Small cohort study & $n=30$ & $\begin{array}{l}\text { One cycle of triple therapy with verteporfin } \\
\text { (photodynamic therapy), dexamethasone (GR agonist), } \\
\text { and bevacizumab (anti-VEGF) improved visual acuity of } \\
\text { CNV patients. }\end{array}$ \\
\hline $\begin{array}{l}\text { Gallemore et al., 2017. The } \\
\text { RADICAL Study [91] }\end{array}$ & GRs & $\begin{array}{l}\text { Randomized } \\
\text { control study }\end{array}$ & $n=162$ & $\begin{array}{l}\text { Combined therapy with verteporfin (photodynamic } \\
\text { therapy), ranibizumab (anti-VEGF) and dexamethasone } \\
\text { (GR agonist) significantly reduced retreatment visits } \\
\text { than ranibizumab treatment alone in CNV patients. }\end{array}$ \\
\hline Capuano et al., 2019 [79] & GRs & Small cohort study & $n=3$ & $\begin{array}{l}\text { Intravitreal implants of dexamethasone (GR agonist) } \\
\text { improved the vision of pregnant CNV patients. }\end{array}$ \\
\hline
\end{tabular}

\section{Nuclear Receptor Signaling in the Pathogenesis of Diabetic Retinopathy}

\subsection{Overview of Diabetic Retinopathy}

Diabetic retinopathy (DR) impacts the lives of hundreds of millions across the globe [92]. Changes in the retinal vasculature, marked by physiologic and pathologic abnormalities (Figure 3), are vast, and yet abnormal vessel growth and macular edema remain the leading concerns related to vision loss [93]. Primary risk factors for DR include the duration of diabetes, hemoglobin $\mathrm{A}_{1 \mathrm{c}}$, hypertension, hyperlipidemia, and hyperglycemia [94-96]. Clinical findings for diabetic retinopathy present along a spectrum of severity, beginning with microaneurysm(s) (mild non-proliferative diabetic retinopathy; NPDR) and advancing to visible neovascularization and angiogenesis (proliferative diabetic retinopathy; PDR) [97]. The disease progression of DR at the molecular level is not well understood; still, several pathways have been shown to be highly involved in the process (Figure 4). These pathways are exacerbated by conditions of hyperglycemia and elevated mitochondrial reactive oxygen species (mROS), resulting in neurovascular damage dictated by oxidative stress, apoptosis, lipid dysregulation, and inflammation $[98,99]$. Our understanding of the molecular mechanisms is ever expanding. An area of promise is the involvement of nuclear receptors, namely PPARs, LXRs, vitamin D receptor 
(VDR), retinoic acid receptor-related orphan receptors (RORs), Rev-ErbAs, glucocorticoid receptor (GR), and mineralocorticoid receptor (MR).
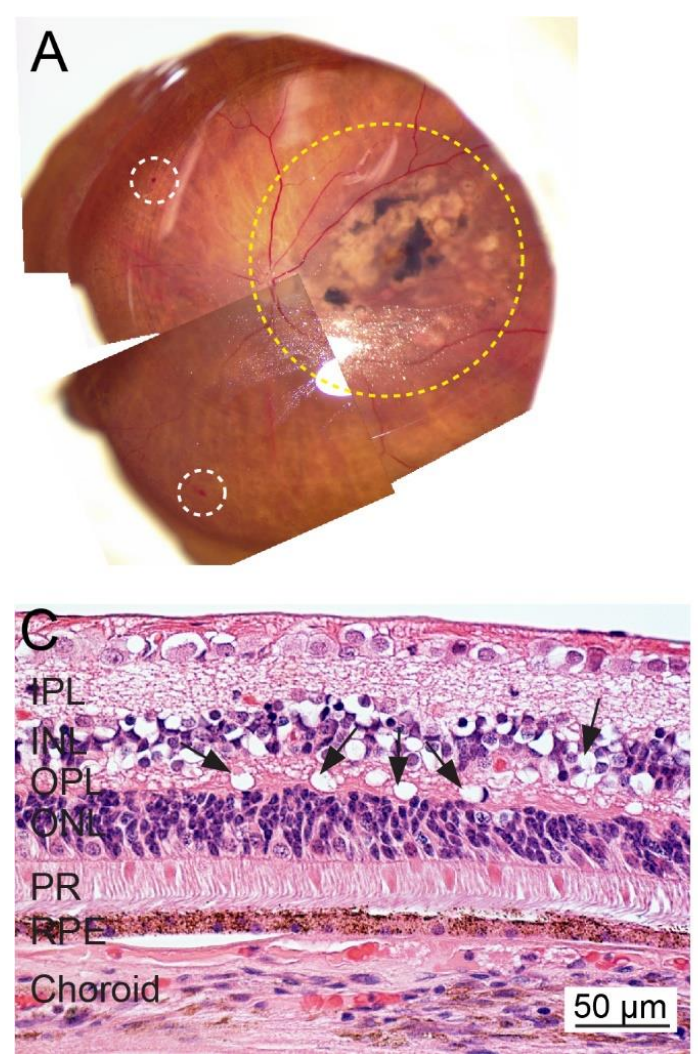
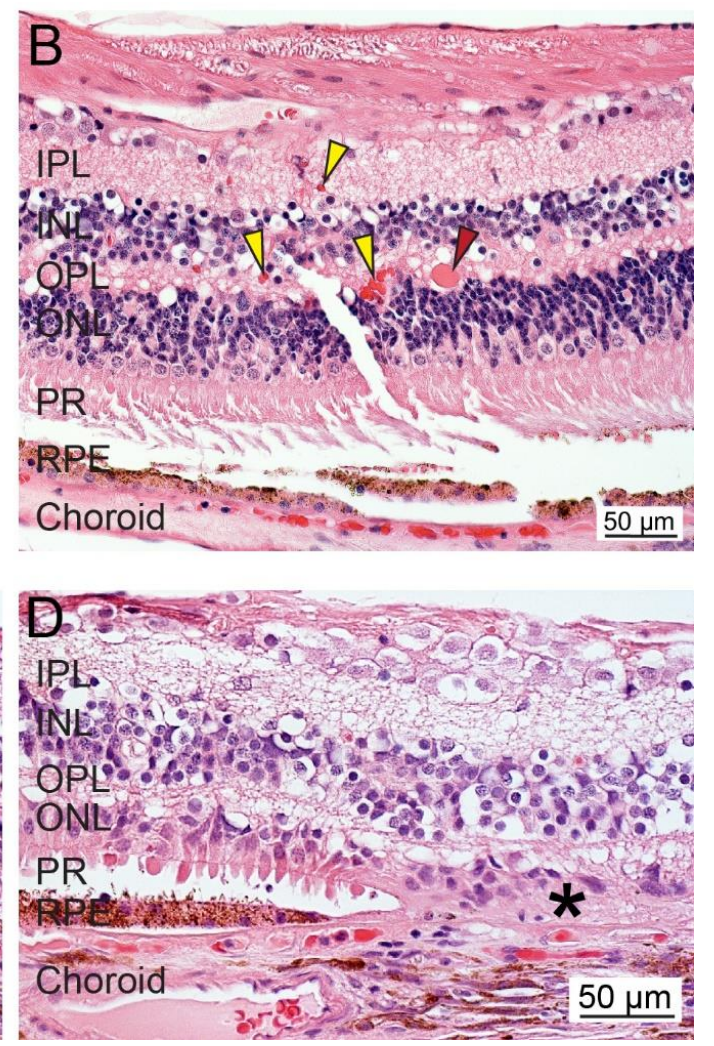

Figure 3. Ex vivo whole tissue and cross-sectional histopathology of human diabetic retinopathy (DR). (A) The representative fundus image of an eye from a patient diagnosed with DR, glaucoma, and AMD (OS; 70-year-old female; death to recovery: $4 \mathrm{~h} 35 \mathrm{~min}$; cause of death: Parkinson's). The area with severe lesions is delineated with a yellow dotted line. The white dotted circle indicates hemorrhages. (B-D) Representative photomicrographs of paraformaldehyde-fixed paraffin-embedded cross-sections of the retina stained with hematoxylin and eosin. Diabetic macular edema fluid was found in the retina (red arrowhead). Some areas showed intact RPE cells, while the retina contains increased infiltrated blood cells (yellow arrowheads) and exhibits vacuolization and atrophy (black arrows). Loss of photoreceptors and RPE cells is noted (asterisks). IPL, inner plexiform layer; INL, inner nuclear layer; OPL, outer plexiform layer; ONL, outer nuclear layer; PR, photoreceptor; RPE, retinal pigment epithelium. Bar $=50 \mu \mathrm{m}$.

\subsection{Nuclear Receptors and Diabetic Retinopathy}

\subsubsection{Peroxisome Proliferator-Activated Receptors (PPARs)}

PPARs are ubiquitously expressed in endothelial tissue types, making them a probable therapeutic target for angiogenic diseases [100]. As such, they have been under investigation in ocular diseases complicated by angiogenesis, including as mentioned earlier AMD, and as will be reviewed below, DR. Of the three sub-types, PPAR $\alpha$ is most implicated in the underlying mechanisms of diabetic retinopathy. Hu et al. established the presence of PPAR $\alpha$ in human and rat retina by immunofluorescent staining and found reduced expression levels in diabetic retinopathy human sections [101]. PPAR $\alpha$ mRNA and protein expression levels were markedly reduced in diabetic animal models, including the STZ-induced diabetic rats, Akita mice, and $\mathrm{db} / \mathrm{db}$ mice. These results were confirmed in several retinal cell lines (hTERT RPE cells, rMC-1 rat muller cells, and primary human retinal capillary pericytes) by treatment for $72 \mathrm{~h}$ with high glucose. In all models, PPAR $\beta / \delta$ and PPAR $\gamma$ expression levels were 
unchanged. Furthermore, it was found that PPAR- $\alpha$ knockout mice retained greater retinal vascular leakage, leukostasis, pericyte loss, capillary loss, capillary degeneration, and the over-expression of inflammatory markers. Of therapeutic relevance, fenofibrate, a potent PPAR $\alpha$ agonist originally considered to have roles in lipid regulation [102], anti-inflammation [103,104], and anti-apoptosis [105], has shown promise in clinical trials as a possible oral treatment option for diabetic retinopathy by preventing microvascular complications [106]. In vivo, fenofibrate is rapidly converted to fenofibric acid by plasma and tissue esterases and consecutively binds to PPAR $\alpha$ to promote the formation of PPAR $\alpha$-RXR heterodimers and downstream target gene expression [107]. In terms of angiogenic capacity, PPAR $\alpha$ activation is known to inhibit SP1 activity, matrix metalloproteinases, VEGF, bFGF, LRP6 phosphorylation, WNT signaling, endothelial cell proliferation, and capillary tube formation while increasing TSP-1 and endostatin activity $[107,108]$. Taken together, PPAR- $\alpha$ is directly implicated in the progression of diabetic retinopathy.

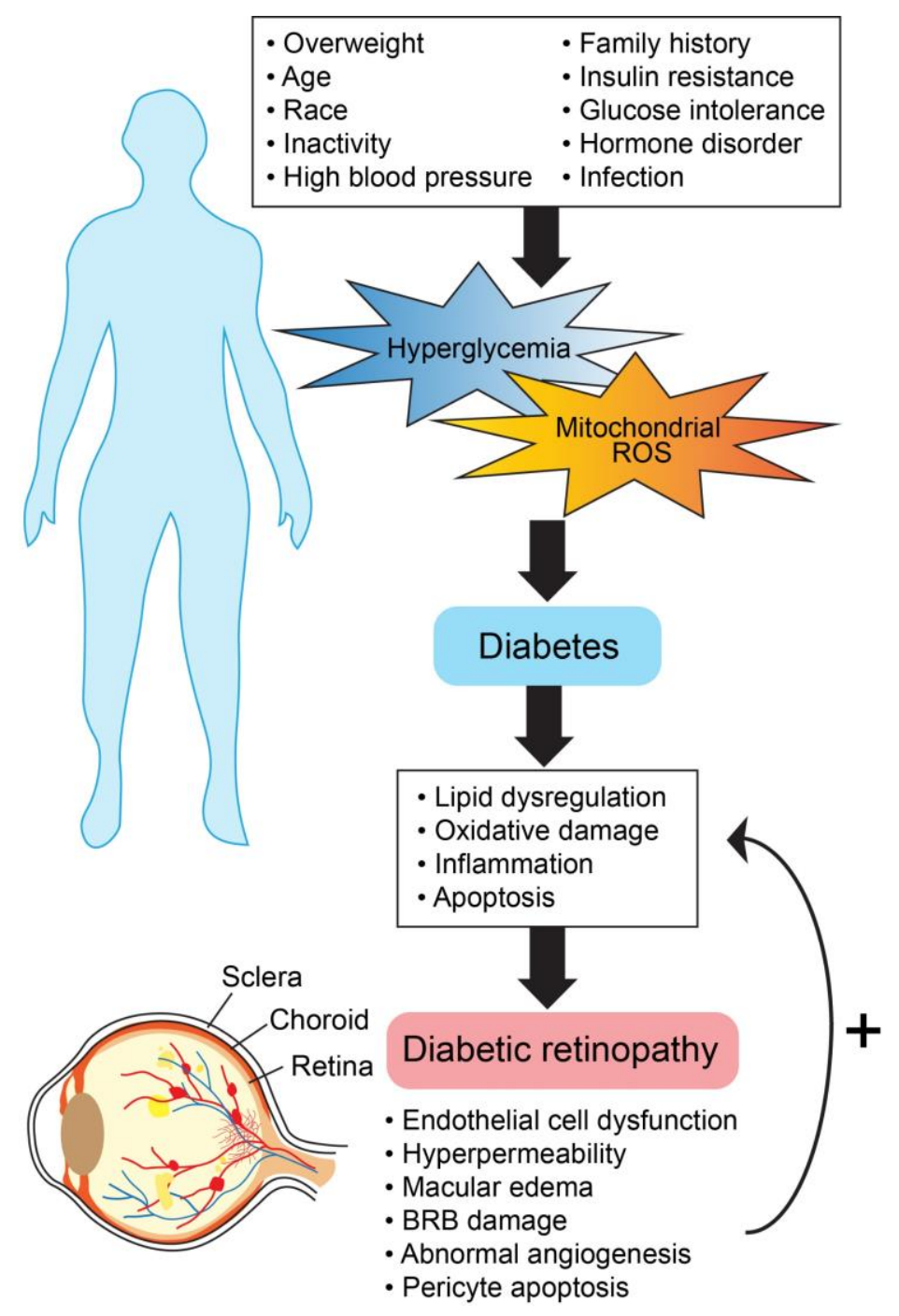

Figure 4. General molecular mechanisms involved in diabetic retinopathy progression.

$\operatorname{PPAR} \beta / \delta$ and PPAR $\gamma$ have also been identified as potential therapeutic targets for pathogenesis. The role of PPAR $\beta / \delta$ in ocular angiogenesis is mainly pro-angiogenic, yet contradictory evidence is reported in various non-ocular endothelial tissue types [108]. In vitro treatment of primary human retinal microvascular endothelial cells with GW0742, a PPAR $\beta / \delta$ agonist, and GSK0660, a PPAR $\beta / \delta$ antagonist, revealed dose-response increases and decreases in tube formation, respectively [109]. 
Results were complemented in vivo. Rat model intravitreal injections of GW0742 exacerbated preretinal neovascularization and GSK0660 prevented preretinal neovascularization, suggesting the potential role that PPAR $\beta / \delta$ could have in treating ocular angiogenesis. PPAR $\gamma$ is a well-characterized target for the insulin-sensitizing drugs called thiazolidinediones [110]. Key roles of PPAR $\gamma$ include glucose metabolism, inflammation, and angiogenesis [111]. Early studies have linked certain risk mutations in PPAR $\gamma$ with DR $[112,113]$, and the presence of PPAR $\gamma$ in the vitreous and aqueous humor suggests its involvement in DR [114]. Conversely, PPAR $\gamma$ expression is suppressed in diabetes-induced streptozotocin wild-type mice and high glucose-treated human umbilical vein endothelial cells (HUVECs) [115].

\subsubsection{Liver-X-Receptors (LXR)}

Lipid dysregulation is hallmark of DR, as such, LXR have also been studied extensively in the pathogenesis of the disease $[116,117]$. In a seminal study by Hazra et al., oxygen-induced retinopathy (OIR) mice were treated with GW3965, an LXR agonist. Compared to untreated mice, GW3965-treated OIR mice marked a $30 \%$ reduction in preretinal blood vessels, which is an end-point measurement of angiogenesis [118]. The mechanisms of action of LXR activation in DR have further been investigated, and it has been shown to restore reverse cholesterol metabolism, prevent inflammation, reduce pro-inflammatory macrophage activity, and prevent the formation of diabetes-induced acellular capillaries [116].

\subsubsection{Vitamin D Receptor}

The vitamin D receptor (VDR) is another ligand-binding nuclear receptor with therapeutic relevance to the progression of angiogenesis in diabetic retinopathy. VDR is activated by 1,25-dihydroxyvitamin $\mathrm{D}_{3}$, a direct metabolite of vitamin $\mathrm{D}$, and constitutively dimerizes with RXR to regulate target gene expression by binding vitamin $\mathrm{D}$ response elements [119]. The connection between VDR and DR is not well understood at the molecular level. However, Merrigan and Kennedy [120] utilized an unbiased phenotype screening protocol to identify small molecule regulators of ocular angiogenesis. Calcitriol, an agonist of VDR, was identified and tested alongside other known VDR agonists (calcipotriol, seocalcitrol, and maxacalcitrol) in zebrafish. VDR activation suggested an anti-angiogenic response, which may help to explain the association between VDR and DR.

\subsubsection{Retinoic Acid Receptor (RORs) and Rev-Erbs}

Retinoic acid receptor-related orphan receptors (RORs) and Rev-ErbAs are two nuclear receptors that share DNA-binding homology at ROR response elements, and in many cases antagonize each other [121-123]. The main structural difference between these two nuclear receptors is the presence of activation function 2 (AF-2) regions in RORs and absence in Rev-ErbAs [124]. The lack of AF-2 in Rev-ErbA allows for the recruitment of repressors such as nuclear repressor corepressor (NCOR) [122]. The natural ligand(s) for RORs are controversial, but there is some consensus that oxysterols are high affinity substrates, similar to LXRs $[125,126]$. On the other hand, the natural ligand for Rev-ErbAs is heme [123].

In an ischemia-induced mouse model, homozygous staggerer mutant mice $\left(R O R^{s g / s g}\right)$ were compared to wild type C57BL/6 mice and demonstrated a 2-fold increase in angiographic score, 3-fold increase in capillary density, increases in eNOS expression levels, and decreases in IL-12 levels [127]. Interestingly, other ocular studies indicate ROR $\alpha$ to have a proangiogenic role by suppressing target genes suppressors of cytokine signaling 3 (SOCS3) and semaphorin 3E (Sema-3E) in OIR and angiogenic mouse models $[128,129]$. SOCS3 and Sema-3E are established antiangiogenic factors. SOCS3 acts as an endogenous inhibitor of pathologic angiogenesis by regulating inflammation and growth factor signaling [130], and Sema-3E-PlexinD1 signaling helps orchestrate new blood vessels formation specifically toward ischemic regions while retaining antiangiogenic capabilities [131-133]. 
Importantly, several studies have identified RORs and Rev-ErbAs as regulators of circadian rhythm, lipid homeostasis, and angiogenesis [122,134]. Others suggest that an interconnected relationship may exist between these functions and systemic and ocular-related vascular diseases [128,135-139]. In a rat model of diabetic mellitus type 2, Busik et al. discovered DR to be a downstream consequence to bone marrow neuropathy succeeded by decreases in endothelial progenitor cell (EPC) number, migratory potential, and reparative capacity. Changes in EPC function were dictated by decreases in circadian patterns and expression levels of circadian-related genes, including ROR $\alpha$ [140].

\subsubsection{Mineralocorticoid Receptors (MR) and Glucocorticoid Receptors (GR)}

MR and GRs are nuclear receptors that share binding potential with aldosterone, cortisol, and corticosterone [141]. Targeting these NRs with steroids has been used in the treatment of systemic vascular diseases and has shed light onto its use in diabetic retinopathy [142,143]. In a rat model of OIR and OIR-stimulated bovine retinal endothelial cells, treatment with spironolactone, an antagonist of MR, was found to be antiangiogenic. Furthermore, protein and mRNA levels of genes involved in retinal inflammation, leukostasis, and monocyte chemoattractant- 1 were reduced [144].

While our understanding of GR is not well-established at the molecular level, glucocorticoids are a common treatment method for diabetic macular edema. Glucocorticoids activate GR and protect the blood-retina barrier by increasing endothelial cell tight junctions [145]. Evidence also suggests that glucocorticoids may act on GR to inhibit VEGF expression and angiogenic capacity [146].

\subsection{Human Studies Examining the Potential Role of Nuclear Receptors in Diabetic Retinopathy.}

Similar to AMD, there are a number of case studies and clinical trials that have either been completed (Table 2) or are ongoing intending on determining the therapeutic potential of nuclear receptors in diabetic retinopathy.

Table 2. Summary of relevant NRs in human studies of DR.

\begin{tabular}{|c|c|c|c|c|}
\hline Reference & Target & Type of Study & Study size & Results and Interpretation \\
\hline $\begin{array}{l}\text { ACCORD Study Group et al., } \\
2014[106]\end{array}$ & $\operatorname{PPAR} \alpha$ & $\begin{array}{l}\text { Randomized, } \\
\text { controlled clinical } \\
\text { trial }\end{array}$ & $\begin{array}{l}n=1593 \text { type II diabetes } \\
\text { mellitus patients ( } 806 \\
\text { fenofibrate treatment; } \\
787 \text { placebo) }\end{array}$ & $\begin{array}{l}\text { Patients treated with fenofibrate, a potent PPAR } \alpha \\
\text { agonist, were less likely to develop diabetic } \\
\text { retinopathy (adjusted OR }=0.60 ; 95 \% \text { CI } 0.42-0.87 \text {; } \\
\qquad p=0.006 \text { ). }\end{array}$ \\
\hline Costa V et al., 2009 [112] & $\operatorname{PPAR} \gamma$ & Case control & $\begin{array}{c}n=670 \text { (211 type II diabetes; } \\
205 \text { obese; } 254 \text { control } \\
\text { individuals })\end{array}$ & $\begin{array}{l}\text { Pro12Ala polymorphism of the } P P A R \gamma \text { gene may be } \\
\text { associated with decreased risk of DR. }\end{array}$ \\
\hline Taverna et al., 2002 [147] & VDR & Cross-sectional & $\begin{array}{l}n=200 \text { c-peptide } \\
\text { negative type I } \\
\text { diabetics }\end{array}$ & $\begin{array}{l}\text { Homozygous wild-type (TT) individuals had lower } \\
\text { odds of "severe" diabetic retinopathy (OR = 0.50; } \\
95 \% \text { CI, } 0.26-0.94 ; p=0.02)\end{array}$ \\
\hline Taverna et al., 2005 [148] & VDR & Cross-sectional & $\begin{array}{c}n=254 \\
\text { c-peptide negative type I } \\
\text { diabetics }\end{array}$ & $\begin{array}{l}\text { Those with severe DR were less likely to have the FF } \\
\text { genotype than those individuals with none or mild } \\
\text { DR (OR }=0.54 ; 95 \% \text { CI, } 0.32-0.90) \text {. }\end{array}$ \\
\hline Jia et al., 2015 [151] & VDR & Case control & $\begin{array}{c}\text { Cases }=81 \\
\text { Controls }=113\end{array}$ & $\begin{array}{l}\text { TAQI T allele }(\mathrm{OR}=2.78 ; 95 \% \mathrm{CI}, 1.15-6.72) \text { and } \\
\text { BSMI } \mathrm{b} \text { allele }(\mathrm{OR}=3.20 ; 95 \% \mathrm{CI}, 1.19-8.60) \text { in VDR } \\
\text { gene are associated with diabetic retinopathy. }\end{array}$ \\
\hline
\end{tabular}

\section{The Future of Nuclear Receptor Targeted Therapies for Ocular Neovascular Diseases}

Abnormal angiogenesis is a common denominator among many systemic and neurodegenerative diseases. The plethora of studies on the role of nuclear receptors in vasculogenesis and angiogenesis in non-ocular tissues dictates the need to explore their potential role in the eye. Although studying NR biology in eye diseases is relatively new, herein, we presented a brief summary of the studies to date that have demonstrated the value of investigating the role of nuclear receptors in ocular angiogenesis 
and vascular disease. These studies are continuing and ever expanding to other ocular vascular diseases not covered in this review due to space limitations, including but not limited to the retinopathy of prematurity, in which RORs, PPARs and ERs have been shown to play a role and central serous chorioretinopathy in which MRs have been implicated. Overall, it is clear that the role of NRs in ocular diseases, similar to other tissues, is diverse and complicated; however, success in harnessing the power of NR targeting in the eye will continue to improve with growing access to relevant in vitro and in vivo models as well as new nuclear receptor pharmacological agents including selective NR modulators.

Author Contributions: Conceptualization: G.M. Writing and editing: P.-L.Y., J.P., and G.M. All authors have read and agree to the published version of the manuscript.

Funding: This research was funded by National Eye Institute grants R01 EY027802 (to G.M), EY028160 (to G.M) and P30 EY005722 (to Duke Eye Center) and Research to Prevent Blindness, Inc (RPB) Core grant (to Duke Eye Center).

Conflicts of Interest: The authors declare no conflict of interest.

\section{References}

1. Potente, M.; Makinen, T. Vascular heterogeneity and specialization in development and disease. Nat. Rev. Mol. Cell Biol. 2017, 18, 477-494. [CrossRef] [PubMed]

2. Kruger-Genge, A.; Blocki, A.; Franke, R.P.; Jung, F. Vascular Endothelial Cell Biology: An Update. Int. J. Mol. Sci. 2019, 20, 4411. [CrossRef] [PubMed]

3. Patel-Hett, S.; D'Amore, P.A. Signal transduction in vasculogenesis and developmental angiogenesis. Int. J. Dev. Biol. 2011, 55, 353-363. [CrossRef] [PubMed]

4. Naito, H.; Iba, T.; Takakura, N. Mechanisms of new blood vessel formation and proliferative heterogeneity of endothelial cells. Int. Immunol. 2020. [CrossRef]

5. Hamik, A.; Wang, B.; Jain, M.K. Transcriptional regulators of angiogenesis. Arterioscler. Thromb. Vasc. Biol. 2006, 26, 1936-1947. [CrossRef]

6. Evans, R.M.; Mangelsdorf, D.J. Nuclear Receptors, RXR, and the Big Bang. Cell 2014, 157, 255-266. [CrossRef]

7. Cheng, H.S.; Lee, J.X.T.; Wahli, W.; Tan, N.S. Exploiting vulnerabilities of cancer by targeting nuclear receptors of stromal cells in tumor microenvironment. Mol. Cancer 2019, 18, 51. [CrossRef]

8. Sherman, M.H.; Downes, M.; Evans, R.M. Nuclear receptors as modulators of the tumor microenvironment. Cancer Prev. Res. (Phila.) 2012, 5, 3-10. [CrossRef]

9. Doan, T.B.; Graham, J.D.; Clarke, C.L. Emerging functional roles of nuclear receptors in breast cancer. J. Mol. Endocrinol. 2017, 58, R169-R190. [CrossRef]

10. Safe, S.; Jin, U.H.; Hedrick, E.; Reeder, A.; Lee, S.O. Minireview: Role of orphan nuclear receptors in cancer and potential as drug targets. Mol. Endocrinol. 2014, 28, 157-172. [CrossRef]

11. Ambati, J.; Fowler, B.J. Mechanisms of age-related macular degeneration. Neuron 2012, 75, 26-39. [CrossRef] [PubMed]

12. Heesterbeek, T.J.; Lores-Motta, L.; Hoyng, C.B.; Lechanteur, Y.T.E.; den Hollander, A.I. Risk factors for progression of age-related macular degeneration. Ophthalmic Physiol. Opt. 2020, 40, 140-170. [CrossRef] [PubMed]

13. Al Gwairi, O.; Thach, L.; Zheng, W.; Osman, N.; Little, P.J. Cellular and Molecular Pathology of Age-Related Macular Degeneration: Potential Role for Proteoglycans. J. Ophthalmol. 2016, 2016, 2913612. [CrossRef] [PubMed]

14. Al-Zamil, W.M.; Yassin, S.A. Recent developments in age-related macular degeneration: A review. Clin. Interv. Aging 2017, 12, 1313-1330. [CrossRef]

15. Hernandez-Zimbron, L.F.; Zamora-Alvarado, R.; Ochoa-De la Paz, L.; Velez-Montoya, R.; Zenteno, E.; Gulias-Canizo, R.; Quiroz-Mercado, H.; Gonzalez-Salinas, R. Age-Related Macular Degeneration: New Paradigms for Treatment and Management of AMD. Oxid. Med. Cell. Longev. 2018, 2018, 8374647. [CrossRef]

16. Malek, G.; Lad, E.M. Emerging roles for nuclear receptors in the pathogenesis of age-related macular degeneration. Cell. Mol. Life Sci. 2014, 71, 4617-4636. [CrossRef]

17. Kim, Y.W.; West, X.Z.; Byzova, T.V. Inflammation and oxidative stress in angiogenesis and vascular disease. J. Mol. Med. (Berl.) 2013, 91, 323-328. [CrossRef] 
18. Yeo, N.J.Y.; Chan, E.J.J.; Cheung, C. Choroidal Neovascularization: Mechanisms of Endothelial Dysfunction. Front Pharmacol. 2019, 10, 1363. [CrossRef]

19. Campa, C.; Costagliola, C.; Incorvaia, C.; Sheridan, C.; Semeraro, F.; De Nadai, K.; Sebastiani, A.; Parmeggiani, F. Inflammatory mediators and angiogenic factors in choroidal neovascularization: Pathogenetic interactions and therapeutic implications. Mediat. Inflamm. 2010, 2010, 546826. [CrossRef]

20. Holekamp, N.M. Review of neovascular age-related macular degeneration treatment options. Am. J. Manag. Care 2019, 25, S172-S181.

21. Khanna, S.; Komati, R.; Eichenbaum, D.A.; Hariprasad, I.; Ciulla, T.A.; Hariprasad, S.M. Current and upcoming anti-VEGF therapies and dosing strategies for the treatment of neovascular AMD: A comparative review. BMJ Open Ophthalmol. 2019, 4, e000398. [CrossRef] [PubMed]

22. Kovach, J.L.; Schwartz, S.G.; Flynn, H.W., Jr.; Scott, I.U. Anti-VEGF Treatment Strategies for Wet AMD. J. Ophthalmol. 2012, 2012, 786870. [CrossRef] [PubMed]

23. Yang, S.; Zhao, J.; Sun, X. Resistance to anti-VEGF therapy in neovascular age-related macular degeneration: A comprehensive review. Drug Des. Devel. Ther. 2016, 10, 1857-1867. [PubMed]

24. Rofagha, S.; Bhisitkul, R.B.; Boyer, D.S.; Sadda, S.R.; Zhang, K.; Group, S.-U.S. Seven-year outcomes in ranibizumab-treated patients in ANCHOR, MARINA, and HORIZON: A multicenter cohort study (SEVEN-UP). Ophthalmology 2013, 120, 2292-2299. [CrossRef]

25. Sadda, S.R.; Guymer, R.; Mones, J.M.; Tufail, A.; Jaffe, G.J. Anti-Vascular Endothelial Growth Factor Use and Atrophy in Neovascular Age-Related Macular Degeneration: Systematic Literature Review and Expert Opinion. Ophthalmology 2020, 127, 648-659. [CrossRef]

26. Saint-Geniez, M.; Kurihara, T.; Sekiyama, E.; Maldonado, A.E.; D’Amore, P.A. An essential role for RPE-derived soluble VEGF in the maintenance of the choriocapillaris. Proc. Natl. Acad. Sci. USA 2009, 106, 18751-18756. [CrossRef]

27. Dwyer, M.A.; Kazmin, D.; Hu, P.; McDonnell, D.P.; Malek, G. Research resource: Nuclear receptor atlas of human retinal pigment epithelial cells: Potential relevance to age-related macular degeneration. Mol. Endocrinol. 2011, 25, 360-372. [CrossRef]

28. Choudhary, M.; Malek, G. Rethinking Nuclear Receptors as Potential Therapeutic Targets for Retinal Diseases. J. Biomol. Screen 2016, 21, 1007-1018. [CrossRef]

29. Forrest, D.; Swaroop, A. Minireview: The role of nuclear receptors in photoreceptor differentiation and disease. Mol. Endocrinol. 2012, 26, 905-915. [CrossRef]

30. Liu, K.; Zou, C.; Qin, B. The association between nuclear receptors and ocular diseases. Oncotarget 2017, 8, 27603-27615. [CrossRef]

31. Tyagi, S.; Gupta, P.; Saini, A.S.; Kaushal, C.; Sharma, S. The peroxisome proliferator-activated receptor: A family of nuclear receptors role in various diseases. J. Adv. Pharm. Technol. Res. 2011, 2, 236-240. [CrossRef] [PubMed]

32. Chan, L.S.A.; Wells, R.A. Cross-Talk between PPARs and the Partners of RXR: A Molecular Perspective. PPAR Res. 2009, 2009, 925309. [CrossRef] [PubMed]

33. Issemann, I.; Green, S. Activation of a member of the steroid hormone receptor superfamily by peroxisome proliferators. Nature 1990, 347, 645-650. [CrossRef] [PubMed]

34. Mirza, A.Z.; Althagafi, I.I.; Shamshad, H. Role of PPAR receptor in different diseases and their ligands: Physiological importance and clinical implications. Eur. J. Med. Chem. 2019, 166, 502-513. [CrossRef] [PubMed]

35. Peters, J.M.; Shah, Y.M.; Gonzalez, F.J. The role of peroxisome proliferator-activated receptors in carcinogenesis and chemoprevention. Nat. Rev. Cancer 2012, 12, 181-195. [CrossRef]

36. Herzlich, A.A.; Ding, X.; Shen, D.; Ross, R.J.; Tuo, J.; Chan, C.C. Peroxisome Proliferator-Activated Receptor Expression in Murine Models and Humans with Age-related Macular Degeneration. Open Biol. J. 2009, 2, 141-148. [CrossRef] [PubMed]

37. SanGiovanni, J.P.; Chew, E.Y. The role of omega-3 long-chain polyunsaturated fatty acids in health and disease of the retina. Prog. Retin. Eye Res. 2005, 24, 87-138. [CrossRef]

38. Chong, E.W.; Kreis, A.J.; Wong, T.Y.; Simpson, J.A.; Guymer, R.H. Dietary omega-3 fatty acid and fish intake in the primary prevention of age-related macular degeneration: A systematic review and meta-analysis. Arch. Ophthalmol. 2008, 126, 826-833. [CrossRef] 
39. Fu, Z.; Liegl, R.; Wang, Z.; Gong, Y.; Liu, C.H.; Sun, Y.; Cakir, B.; Burnim, S.B.; Meng, S.S.; Lofqvist, C.; et al. Adiponectin Mediates Dietary Omega-3 Long-Chain Polyunsaturated Fatty Acid Protection Against Choroidal Neovascularization in Mice. Investig. Ophthalmol. Vis. Sci. 2017, 58, 3862-3870. [CrossRef]

40. Fu, Z.; Lofqvist, C.A.; Shao, Z.; Sun, Y.; Joyal, J.S.; Hurst, C.G.; Cui, R.Z.; Evans, L.P.; Tian, K.; SanGiovanni, J.P.; et al. Dietary omega-3 polyunsaturated fatty acids decrease retinal neovascularization by adipose-endoplasmic reticulum stress reduction to increase adiponectin. Am. J. Clin. Nutr. 2015, 101, 879-888. [CrossRef]

41. Gong, Y.; Shao, Z.; Fu, Z.; Edin, M.L.; Sun, Y.; Liegl, R.G.; Wang, Z.; Liu, C.H.; Burnim, S.B.; Meng, S.S.; et al. Fenofibrate Inhibits Cytochrome P450 Epoxygenase 2C Activity to Suppress Pathological Ocular Angiogenesis. EBioMedicine 2016, 13, 201-211. [CrossRef] [PubMed]

42. SanGiovanni, J.P.; Chen, J.; Sapieha, P.; Aderman, C.M.; Stahl, A.; Clemons, T.E.; Chew, E.Y.; Smith, L.E. DNA sequence variants in PPARGC1A, a gene encoding a coactivator of the omega-3 LCPUFA sensing PPAR-RXR transcription complex, are associated with NV AMD and AMD-associated loci in genes of complement and VEGF signaling pathways. PLoS ONE 2013, 8, e53155. [CrossRef] [PubMed]

43. Qiu, F.; Matlock, G.; Chen, Q.; Zhou, K.; Du, Y.; Wang, X.; Ma, J.X. Therapeutic Effects of PPARalpha Agonist on Ocular Neovascularization in Models Recapitulating Neovascular Age-Related Macular Degeneration. Investig. Ophthalmol. Vis. Sci. 2017, 58, 5065-5075. [CrossRef] [PubMed]

44. Murata, T.; He, S.; Hangai, M.; Ishibashi, T.; Xi, X.P.; Kim, S.; Hsueh, W.A.; Ryan, S.J.; Law, R.E.; Hinton, D.R. Peroxisome proliferator-activated receptor-gamma ligands inhibit choroidal neovascularization. Investig. Ophthalmol. Vis. Sci. 2000, 41, 2309-2317.

45. Chang, J.Y.; Bora, P.S.; Bora, N.S. Prevention of Oxidative Stress-Induced Retinal Pigment Epithelial Cell Death by the PPARgamma Agonists, 15-Deoxy-Delta12,14-Prostaglandin J(2). PPAR Res. 2008, 2008, 720163. [CrossRef]

46. Piqueras, L.; Reynolds, A.R.; Hodivala-Dilke, K.M.; Alfranca, A.; Redondo, J.M.; Hatae, T.; Tanabe, T.; Warner, T.D.; Bishop-Bailey, D. Activation of PPARbeta/delta induces endothelial cell proliferation and angiogenesis. Arterioscler. Thromb. Vasc. Biol. 2007, 27, 63-69. [CrossRef]

47. Wang, B.; Tontonoz, P. Liver X receptors in lipid signalling and membrane homeostasis. Nat. Rev. Endocrinol. 2018, 14, 452-463. [CrossRef]

48. Fessler, M.B. The challenges and promise of targeting the Liver X Receptors for treatment of inflammatory disease. Pharmacol. Ther. 2018, 181, 1-12. [CrossRef]

49. Ghisletti, S.; Huang, W.; Ogawa, S.; Pascual, G.; Lin, M.-E.; Willson, T.M.; Rosenfeld, M.G.; Glass, C.K. Parallel SUMOylation-dependent pathways mediate gene- and signal-specific transrepression by LXRs and PPARgamma. Mol. Cell 2007, 25, 57-70. [CrossRef]

50. Choudhary, M.; Ismail, E.N.; Yao, P.L.; Tayyari, F.; Radu, R.A.; Nusinowitz, S.; Boulton, M.E.; Apte, R.S.; Ruberti, J.W.; Handa, J.T.; et al. LXRs regulate features of age-related macular degeneration and may be a potential therapeutic target. JCI Insight 2020, 5, e131928. [CrossRef]

51. Song, X.Y.; Wu, W.F.; Gabbi, C.; Dai, Y.B.; So, M.; Chaurasiya, S.P.; Wang, L.; Warner, M.; Gustafsson, J.A. Retinal and optic nerve degeneration in liver $\mathrm{X}$ receptor beta knockout mice. Proc. Natl. Acad. Sci. USA 2019, 116, 16507-16512. [CrossRef] [PubMed]

52. Zheng, S.; Yang, H.; Chen, Z.; Zheng, C.; Lei, C.; Lei, B. Activation of liver X receptor protects inner retinal damage induced by N-methyl-D-aspartate. Investig. Ophthalmol. Vis. Sci. 2015, 56, 1168-1180. [CrossRef] [PubMed]

53. Mukwaya, A.; Lennikov, A.; Xeroudaki, M.; Mirabelli, P.; Lachota, M.; Jensen, L.; Peebo, B.; Lagali, N. Time-dependent LXR/RXR pathway modulation characterizes capillary remodeling in inflammatory corneal neovascularization. Angiogenesis 2018, 21, 395-413. [CrossRef] [PubMed]

54. Sene, A.; Khan, A.A.; Cox, D.; Nakamura, R.E.; Santeford, A.; Kim, B.M.; Sidhu, R.; Onken, M.D.; Harbour, J.W.; Hagbi-Levi, S.; et al. Impaired cholesterol efflux in senescent macrophages promotes age-related macular degeneration. Cell Metab. 2013, 17, 549-561. [CrossRef] [PubMed]

55. Hutchinson, C.V.; Walker, J.A.; Davidson, C. Oestrogen, ocular function and low-level vision: A review. J. Endocrinol. 2014, 223, R9-R18. [CrossRef] [PubMed]

56. Tanemura, M.; Miyamoto, N.; Mandai, M.; Kamizuru, H.; Ooto, S.; Yasukawa, T.; Takahashi, M.; Honda, Y. The role of estrogen and estrogen receptorbeta in choroidal neovascularization. Mol. Vis. 2004, 10, 923-932. 
57. Javitt, J.C.; Zhou, Z.; Maguire, M.G.; Fine, S.L.; Willke, R.J. Incidence of exudative age-related macular degeneration among elderly Americans. Ophthalmology 2003, 110, 1534-1539. [CrossRef]

58. Rudnicka, A.R.; Jarrar, Z.; Wormald, R.; Cook, D.G.; Fletcher, A.; Owen, C.G. Age and gender variations in age-related macular degeneration prevalence in populations of European ancestry: A meta-analysis. Ophthalmology 2012, 119, 571-580. [CrossRef]

59. Espinosa-Heidmann, D.G.; Marin-Castano, M.E.; Pereira-Simon, S.; Hernandez, E.P.; Elliot, S.; Cousins, S.W. Gender and estrogen supplementation increases severity of experimental choroidal neovascularization. Exp. Eye Res. 2005, 80, 413-423. [CrossRef]

60. Boekhoorn, S.S.; Vingerling, J.R.; Uitterlinden, A.G.; Van Meurs, J.B.; van Duijn, C.M.; Pols, H.A.; Hofman, A.; de Jong, P.T. Estrogen receptor alpha gene polymorphisms associated with incident aging macula disorder. Investig. Ophthalmol. Vis. Sci. 2007, 48, 1012-1017. [CrossRef]

61. Seitzman, R.L.; Mahajan, V.B.; Mangione, C.; Cauley, J.A.; Ensrud, K.E.; Stone, K.L.; Cummings, S.R.; Hochberg, M.C.; Hillier, T.A.; Sinsheimer, J.S.; et al. Study of Osteoporotic Fractures Research, G., Estrogen receptor alpha and matrix metalloproteinase 2 polymorphisms and age-related maculopathy in older women. Am. J. Epidemiol. 2008, 167, 1217-1225. [CrossRef] [PubMed]

62. Freeman, E.E.; Munoz, B.; Bressler, S.B.; West, S.K. Hormone replacement therapy, reproductive factors, and age-related macular degeneration: The Salisbury Eye Evaluation Project. Ophthalmic Epidemiol. 2005, 12, 37-45. [CrossRef] [PubMed]

63. Edwards, D.R.; Gallins, P.; Polk, M.; Ayala-Haedo, J.; Schwartz, S.G.; Kovach, J.L.; Spencer, K.; Wang, G.; Agarwal, A.; Postel, E.A.; et al. Inverse association of female hormone replacement therapy with age-related macular degeneration and interactions with ARMS2 polymorphisms. Investig. Ophthalmol. Vis. Sci. 2010, 51, 1873-1879. [CrossRef] [PubMed]

64. Snow, K.K.; Cote, J.; Yang, W.; Davis, N.J.; Seddon, J.M. Association between reproductive and hormonal factors and age-related maculopathy in postmenopausal women. Am. J. Ophthalmol. 2002, 134, 842-848. [CrossRef]

65. Dolz-Marco, R.; Domenech, N.; Diago, T.; Montero, J.; Garcia-Canet, S.; Cervera-Taulet, E.; Gallego-Pinazo, R.; Arevalo, J.F. Hormonal Supplementation Triggering Choroidal Neovascularization in Healthy Young Females. Retin. Cases Br. Rep. 2019, 13, 162-166. [CrossRef] [PubMed]

66. Feng, S.; Cao, Z.; Wang, X. Role of aryl hydrocarbon receptor in cancer. Biochim. Biophys. Acta 2013, 1836, 197-210. [CrossRef]

67. Roman, A.C.; Carvajal-Gonzalez, J.M.; Rico-Leo, E.M.; Fernandez-Salguero, P.M. Dioxin receptor deficiency impairs angiogenesis by a mechanism involving VEGF-A depletion in the endothelium and transforming growth factor-beta overexpression in the stroma. J. Biol. Chem. 2009, 284, 25135-25148. [CrossRef]

68. Choudhary, M.; Kazmin, D.; Hu, P.; Thomas, R.S.; McDonnell, D.P.; Malek, G. Aryl hydrocarbon receptor knock-out exacerbates choroidal neovascularization via multiple pathogenic pathways. J. Pathol. 2015, 235, 101-112. [CrossRef]

69. Hu, P.; Herrmann, R.; Bednar, A.; Saloupis, P.; Dwyer, M.A.; Yang, P.; Qi, X.; Thomas, R.S.; Jaffe, G.J.; Boulton, M.E.; et al. Aryl hydrocarbon receptor deficiency causes dysregulated cellular matrix metabolism and age-related macular degeneration-like pathology. Proc. Natl. Acad. Sci. USA 2013, 110, E4069-E4078. [CrossRef]

70. Choudhary, M.; Safe, S.; Malek, G. Suppression of aberrant choroidal neovascularization through activation of the aryl hydrocarbon receptor. Biochim. Biophys. Acta Mol. Basis Dis. 2018, 1864, 1583-1595. [CrossRef]

71. Sulaiman, R.S.; Kadmiel, M.; Cidlowski, J.A. Glucocorticoid receptor signaling in the eye. Steroids 2018, 133, 60-66. [CrossRef]

72. Martens, B.; Drebert, Z. Glucocorticoid-mediated effects on angiogenesis in solid tumors. J. Steroid Biochem. Mol. Biol. 2019, 188, 147-155. [CrossRef] [PubMed]

73. Cain, D.W.; Cidlowski, J.A. Immune regulation by glucocorticoids. Nat. Rev. Immunol. 2017, 17, $233-247$. [CrossRef] [PubMed]

74. Straub, R.H.; Cutolo, M. Glucocorticoids and chronic inflammation. Rheumatology (Oxford) 2016, 55, ii6-ii14. [CrossRef]

75. Ramamoorthy, S.; Cidlowski, J.A. Corticosteroids: Mechanisms of Action in Health and Disease. Rheum. Dis. Clin. N. Am. 2016, 42, 15-31. [CrossRef] [PubMed] 
76. Jin, H.L.; Choi, Y.; Jeong, K.W. Crosstalk between Aryl Hydrocarbon Receptor and Glucocorticoid Receptor in Human Retinal Pigment Epithelial Cells. Int. J. Endocrinol. 2017, 2017, 5679517. [CrossRef] [PubMed]

77. Takata, S.; Masuda, T.; Nakamura, S.; Kuchimaru, T.; Tsuruma, K.; Shimazawa, M.; Nagasawa, H.; Kizaka-Kondoh, S.; Hara, H. The effect of triamcinolone acetonide on laser-induced choroidal neovascularization in mice using a hypoxia visualization bio-imaging probe. Sci. Rep. 2015, 5, 9898. [CrossRef] [PubMed]

78. Ciulla, T.A.; Criswell, M.H.; Danis, R.P.; Hill, T.E. Intravitreal triamcinolone acetonide inhibits choroidal neovascularization in a laser-treated rat model. Arch. Ophthalmol. 2001, 119, 399-404. [CrossRef]

79. Capuano, V.; Serra, R.; Oubraham, H.; Zambrowski, O.; Amana, D.; Zerbib, J.; Souied, E.H.; Querques, G. Dexamethasone Intravitreal Implant for Choroidal Neovascularization during Pregnancy. Retin. Cases Br. Rep. 2019, 13, 300-307. [CrossRef]

80. Bakri, S.J.; Ekdawi, N.S. Intravitreal triamcinolone and bevacizumab combination therapy for refractory choroidal neovascularization with retinal angiomatous proliferation. Eye (Lond.) 2008, 22, 978-980. [CrossRef]

81. Augustin, A.J.; Puls, S.; Offermann, I. Triple therapy for choroidal neovascularization due to age-related macular degeneration: Verteporfin PDT, bevacizumab, and dexamethasone. Retina 2007, 27, 133-140. [CrossRef] [PubMed]

82. Ehmann, D.; Garcia, R. Triple therapy for neovascular age-related macular degeneration (verteporfin photodynamic therapy, intravitreal dexamethasone, and intravitreal bevacizumab). Can. J. Ophthalmol. 2010, 45, 36-40. [CrossRef] [PubMed]

83. Augustin, A. Anecortave acetate in the treatment of age-related macular degeneration. Clin. Interv. Aging 2006, 1, 237-246. [CrossRef] [PubMed]

84. Russell, S.R.; Hudson, H.L.; Jerdan, J.A.; Anecortave Acetate Clinical Study Group. Anecortave acetate for the treatment of exudative age-related macular degeneration-A review of clinical outcomes. Surv. Ophthalmol. 2007, 52, S79-S90. [CrossRef] [PubMed]

85. Rubio, R.G.; Adamis, A.P. Ocular Angiogenesis: Vascular Endothelial Growth Factor and Other Factors. Dev. Ophthalmol. 2016, 55, 28-37.

86. Clark, A.F. Mechanism of action of the angiostatic cortisene anecortave acetate. Surv. Ophthalmol. 2007, 52, S26-S34. [CrossRef]

87. Hong, F.; Xu, P.; Zhai, Y. The Opportunities and Challenges of Peroxisome Proliferator-Activated Receptors Ligands in Clinical Drug Discovery and Development. Int. J. Mol. Sci. 2018, 19, 2189. [CrossRef]

88. Age-Related Eye Disease Study Research Group. Risk factors associated with age-related macular degeneration. A case-control study in the age-related eye disease study: Age-Related Eye Disease Study Report Number 3. Ophthalmology 2000, 107, 2224-2232.

89. Tomany, S.C.; Wang, J.J.; Van Leeuwen, R.; Klein, R.; Mitchell, P.; Vingerling, J.R.; Klein, B.E.; Smith, W.; De Jong, P.T. Risk factors for incident age-related macular degeneration: Pooled findings from 3 continents. Ophthalmology 2004, 111, 1280-1287. [CrossRef]

90. Spaide, R.F.; Sorenson, J.; Maranan, L. Photodynamic therapy with verteporfin combined with intravitreal injection of triamcinolone acetonide for choroidal neovascularization. Ophthalmology 2005, 112, 301-304. [CrossRef]

91. Gallemore, R.P.; Wallsh, J.; Hudson, H.L.; Ho, A.C.; Chace, R.; Pearlman, J. Combination verteporfin photodynamic therapy ranibizumab-dexamethasone in choroidal neovascularization due to age-related macular degeneration: Results of a phase II randomized trial. Clin. Ophthalmol. 2017, 11, 223-231. [CrossRef] [PubMed]

92. Guariguata, L.; Whiting, D.R.; Hambleton, I.; Beagley, J.; Linnenkamp, U.; Shaw, J.E. Global estimates of diabetes prevalence for 2013 and projections for 2035. Diabetes Res. Clin. Pract. 2014, 103, 137-149. [CrossRef]

93. Crawford, T.N.; Alfaro, D.V.; Kerrison, J.B.; Jablon, E.P. Diabetic retinopathy and angiogenesis. Curr. Diabetes Rev. 2009, 5, 8-13. [CrossRef] [PubMed]

94. Yau, J.W.Y.; Rogers, S.L.; Kawasaki, R.; Lamoureux, E.L.; Kowalski, J.W.; Bek, T.; Chen, S.-J.; Dekker, J.M.; Fletcher, A.; Grauslund, J.; et al. Global prevalence and major risk factors of diabetic retinopathy. Diabetes Care 2012, 35, 556-564. [CrossRef]

95. Ballard, D.J.; Melton, L.J.; Dwyer, M.S.; Trautmann, J.C.; Chu, C.P.; O’Fallon, W.M.; Palumbo, P.J. Risk factors for diabetic retinopathy: A population-based study in Rochester, Minnesota. Diabetes Care 1986, 9, 334-342. [CrossRef] [PubMed] 
96. Atchison, E.; Barkmeier, A. The Role of Systemic Risk Factors in Diabetic Retinopathy. Curr. Ophthalmol. Rep. 2016, 4, 84-89. [CrossRef]

97. Wilkinson, C.P.; Ferris, F.L.; Klein, R.E.; Lee, P.P.; Agardh, C.D.; Davis, M.; Dills, D.; Kampik, A.; Pararajasegaram, R.; Verdaguer, J.T.; et al. Proposed international clinical diabetic retinopathy and diabetic macular edema disease severity scales. Ophthalmology 2003, 110, 1677-1682. [CrossRef]

98. Safi, S.Z.; Qvist, R.; Kumar, S.; Batumalaie, K.; Ismail, I.S.B. Molecular mechanisms of diabetic retinopathy, general preventive strategies, and novel therapeutic targets. Bio. Med. Res. Int. 2014, 2014, 801269. [CrossRef]

99. Li, C.; Miao, X.; Li, F.; Wang, S.; Liu, Q.; Wang, Y.; Sun, J. Oxidative Stress-Related Mechanisms and Antioxidant Therapy in Diabetic Retinopathy. Oxidative Med. Cell. Longev. 2017, 2017, 9702820. [CrossRef]

100. Hamblin, M.; Chang, L.; Fan, Y.; Zhang, J.; Chen, Y.E. PPARs and the cardiovascular system. Antioxid. Redox Signal. 2009, 11, 1415-1452. [CrossRef]

101. Hu, Y.; Chen, Y.; Ding, L.; He, X.; Takahashi, Y.; Gao, Y.; Shen, W.; Cheng, R.; Chen, Q.; Qi, X.; et al. Pathogenic role of diabetes-induced PPAR- $\alpha$ down-regulation in microvascular dysfunction. Proc. Natl. Acad. Sci. USA 2013, 110, 15401-15406. [CrossRef]

102. Lefebvre, P.; Chinetti, G.; Fruchart, J.-C.; Staels, B. Sorting out the roles of PPAR alpha in energy metabolism and vascular homeostasis. J. Clin. Investig. 2006, 116, 571-580. [CrossRef] [PubMed]

103. Staels, B.; Koenig, W.; Habib, A.; Merval, R.; Lebret, M.; Torra, I.P.; Delerive, P.; Fadel, A.; Chinetti, G.; Fruchart, J.C.; et al. Activation of human aortic smooth-muscle cells is inhibited by PPARalpha but not by PPARgamma activators. Nature 1998, 393, 790-793. [CrossRef] [PubMed]

104. Delerive, P.; De Bosscher, K.; Besnard, S.; Vanden Berghe, W.; Peters, J.M.; Gonzalez, F.J.; Fruchart, J.C.; Tedgui, A.; Haegeman, G.; Staels, B. Peroxisome proliferator-activated receptor alpha negatively regulates the vascular inflammatory gene response by negative cross-talk with transcription factors NF-kappaB and AP-1. J. Biol. Chem. 1999, 274, 32048-32054. [CrossRef] [PubMed]

105. Kadian, S.; Mahadevan, N.; Balakumar, P. Differential effects of low-dose fenofibrate treatment in diabetic rats with early onset nephropathy and established nephropathy. Eur. J. Pharmacol. 2013, 698, 388-396. [CrossRef] [PubMed]

106. Group, A.S.; Group, A.E.S.; Chew, E.Y.; Ambrosius, W.T.; Davis, M.D.; Danis, R.P.; Gangaputra, S.; Greven, C.M.; Hubbard, L.; Esser, B.A.; et al. Effects of medical therapies on retinopathy progression in type 2 diabetes. N. Engl. J. Med. 2010, 363, 233-244.

107. Noonan, J.E.; Jenkins, A.J.; Ma, J.-X.; Keech, A.C.; Wang, J.J.; Lamoureux, E.L. An update on the molecular actions of fenofibrate and its clinical effects on diabetic retinopathy and other microvascular end points in patients with diabetes. Diabetes 2013, 62, 3968-3975. [CrossRef]

108. Bishop-Bailey, D.; Swales, K.E. The Role of PPARs in the Endothelium: Implications for Cancer Therapy. PPAR Res. 2008, 2008, 904251. [CrossRef]

109. Capozzi, M.E.; McCollum, G.W.; Savage, S.R.; Penn, J.S. Peroxisome proliferator-activated receptor- $\beta / \delta$ regulates angiogenic cell behaviors and oxygen-induced retinopathy. Investig. Ophthalmol. Vis. Sci. 2013, 54, 4197-4207. [CrossRef]

110. Spiegelman, B.M. PPAR-gamma: Adipogenic regulator and thiazolidinedione receptor. Diabetes 1998, 47, 507-514. [CrossRef]

111. Costa, V.; Ciccodicola, A. Is PPARG the key gene in diabetic retinopathy? Br. J. Pharmacol. 2012, 165, 1-3. [CrossRef] [PubMed]

112. Costa, V.; Casamassimi, A.; Esposito, K.; Villani, A.; Capone, M.; Iannella, R.; Schisano, B.; Ciotola, M.; Di Palo, C.; Corrado, F.C.; et al. Characterization of a novel polymorphism in PPARG regulatory region associated with type 2 diabetes and diabetic retinopathy in Italy. J. Biomed. Biotechnol. 2009, 2009, 126917. [CrossRef] [PubMed]

113. Malecki, M.T.; Cyganek, K.; Mirkiewicz-Sieradzka, B.; Wolkow, P.P.; Wanic, K.; Skupien, J.; Solnica, B.; Sieradzki, J. Alanine variant of the Pro12Ala polymorphism of the PPARgamma gene might be associated with decreased risk of diabetic retinopathy in type 2 diabetes. Diabetes Res. Clin. Pract. 2008, 80, 139-145. [CrossRef] [PubMed]

114. Katome, T.; Namekata, K.; Mitamura, Y.; Semba, K.; Egawa, M.; Naito, T.; Harada, C.; Harada, T. Expression of intraocular peroxisome proliferator-activated receptor gamma in patients with proliferative diabetic retinopathy. J. Diabetes Its Complicat. 2015, 29, 275-281. [CrossRef] [PubMed] 
115. Tawfik, A.; Sanders, T.; Kahook, K.; Akeel, S.; Elmarakby, A.; Al-Shabrawey, M. Suppression of retinal peroxisome proliferator-activated receptor gamma in experimental diabetes and oxygen-induced retinopathy: Role of NADPH oxidase. Investig. Ophthalmol. Vis. Sci. 2009, 50, 878-884. [CrossRef]

116. Hammer, S.S.; Beli, E.; Kady, N.; Wang, Q.; Wood, K.; Lydic, T.A.; Malek, G.; Saban, D.R.; Wang, X.X.; Hazra, S.; et al. The Mechanism of Diabetic Retinopathy Pathogenesis Unifying Key Lipid Regulators, Sirtuin 1 and Liver X Receptor. EBioMedicine 2017, 22, 181-190. [CrossRef]

117. Malek, G.; Busik, J.; Grant, M.B.; Choudhary, M. Models of retinal diseases and their applicability in drug discovery. Expert Opin. Drug Discov. 2018, 13, 359-377. [CrossRef]

118. Hazra, S.; Rasheed, A.; Bhatwadekar, A.; Wang, X.; Shaw, L.C.; Patel, M.; Caballero, S.; Magomedova, L.; Solis, N.; Yan, Y.; et al. Liver $X$ receptor modulates diabetic retinopathy outcome in a mouse model of streptozotocin-induced diabetes. Diabetes 2012, 61, 3270-3279. [CrossRef]

119. Von Essen, M.R.; Geisler, C. VDR, the Vitamin D Receptor. In Encyclopedia of Signaling Molecules; Springer International Publishing: Seoul, Korea, 2018.

120. Merrigan, S.L.; Kennedy, B.N. Vitamin D receptor agonists regulate ocular developmental angiogenesis and modulate expression of dre-miR-21 and VEGF. Br. J. Pharmacol. 2017, 174, 2636-2651. [CrossRef]

121. Duez, H.; Staels, B. Rev-erb-alpha: An integrator of circadian rhythms and metabolism. J. Appl. Physiol. (Bethesda Md. 1985) 2009, 107, 1972-1980. [CrossRef]

122. Solt, L.A.; Kojetin, D.J.; Burris, T.P. The REV-ERBs and RORs: Molecular links between circadian rhythms and lipid homeostasis. Future Med. Chem. 2011, 3, 623-638. [CrossRef] [PubMed]

123. Yin, L.; Wu, N.; Lazar, M.A. Nuclear receptor Rev-erbalpha: A heme receptor that coordinates circadian rhythm and metabolism. Nucl. Recept. Signal. 2010, 8, e001. [CrossRef] [PubMed]

124. Wärnmark, A.; Treuter, E.; Wright, A.P.H.; Gustafsson, J.-A. Activation functions 1 and 2 of nuclear receptors: Molecular strategies for transcriptional activation. Mol. Endocrinol. (Baltim. Md.) 2003, 17, 1901-1909. [CrossRef] [PubMed]

125. Solt, L.A.; Burris, T.P. Action of RORs and their ligands in (patho) physiology. Trends Endocrinol. Metab. 2012, 23, 619-627. [CrossRef] [PubMed]

126. Santori, F.R. Nuclear hormone receptors put immunity on sterols. Eur. J. Immunol. 2015, 45, $2730-2741$. [CrossRef]

127. Besnard, S.; Silvestre, J.S.; Duriez, M.; Bakouche, J.; Lemaigre-Dubreuil, Y.; Mariani, J.; Levy, B.I.; Tedgui, A. Increased ischemia-induced angiogenesis in the staggerer mouse, a mutant of the nuclear receptor Roralpha. Circ. Res. 2001, 89, 1209-1215. [CrossRef]

128. Sun, Y.; Liu, C.-H.; SanGiovanni, J.P.; Evans, L.P.; Tian, K.T.; Zhang, B.; Stahl, A.; Pu, W.T.; Kamenecka, T.M.; Solt, L.A.; et al. Nuclear receptor $\mathrm{ROR} \alpha$ regulates pathologic retinal angiogenesis by modulating SOCS3-dependent inflammation. Proc. Natl. Acad. Sci. USA 2015, 112, 10401-10406. [CrossRef]

129. Sun, Y.; Liu, C.-H.; Wang, Z.; Meng, S.S.; Burnim, S.B.; SanGiovanni, J.P.; Kamenecka, T.M.; Solt, L.A.; Chen, J. ROR $\alpha$ modulates semaphorin 3E transcription and neurovascular interaction in pathological retinal angiogenesis. FASEB J. Off. Publ. Fed. Am. Soc. Exp. Biol. 2017, 31, 4492-4502. [CrossRef]

130. Stahl, A.; Joyal, J.-S.; Chen, J.; Sapieha, P.; Juan, A.M.; Hatton, C.J.; Pei, D.T.; Hurst, C.G.; Seaward, M.R.; Krah, N.M.; et al. SOCS3 is an endogenous inhibitor of pathologic angiogenesis. Blood 2012, 120, 2925-2929. [CrossRef]

131. Fukushima, Y.; Okada, M.; Kataoka, H.; Hirashima, M.; Yoshida, Y.; Mann, F.; Gomi, F.; Nishida, K.; Nishikawa, S.-I.; Uemura, A. Sema3E-PlexinD1 signaling selectively suppresses disoriented angiogenesis in ischemic retinopathy in mice. J. Clin. Investig. 2011, 121, 1974-1985. [CrossRef]

132. Kim, J.; Oh, W.-J.; Gaiano, N.; Yoshida, Y.; Gu, C. Semaphorin 3E-Plexin-D1 signaling regulates VEGF function in developmental angiogenesis via a feedback mechanism. Genes. Dev. 2011, 25, 1399-1411. [CrossRef] [PubMed]

133. Moriya, J.; Minamino, T.; Tateno, K.; Okada, S.; Uemura, A.; Shimizu, I.; Yokoyama, M.; Nojima, A.; Okada, M.; Koga, H.; et al. Inhibition of semaphorin as a novel strategy for therapeutic angiogenesis. Circu. Res. 2010, 106, 391-398. [CrossRef] [PubMed]

134. Kim, K.; Boo, K.; Yu, Y.S.; Oh, S.K.; Kim, H.; Jeon, Y.; Bhin, J.; Hwang, D.; Kim, K.I.; Lee, J.-S.; et al. ROR $\alpha$ controls hepatic lipid homeostasis via negative regulation of PPAR $\gamma$ transcriptional network. Nature Commun. 2017, 8, 162. [CrossRef] [PubMed] 
135. Besnard, S.; Heymes, C.; Merval, R.; Rodriguez, M.; Galizzi, J.-P.; Boutin, J.A.; Mariani, J.; Tedgui, A. Expression and regulation of the nuclear receptor RORalpha in human vascular cells. FEBS Lett. 2002, 511, 36-40. [CrossRef]

136. Thosar, S.S.; Butler, M.P.; Shea, S.A. Role of the circadian system in cardiovascular disease. J. Clin. Investig. 2018, 128, 2157-2167.

137. Jensen, L.D.; Cao, Y. Clock controls angiogenesis. Cell Cycle (Georget. Tex.) 2013, 12, 405-408. [CrossRef] [PubMed]

138. Hoshi, T.; Toukairin, Y.; Arai, T.; Nogami, M. Circadian rhythms of angiogenic factors in skin and wound tissue in per2-mutant mice. Biomed. Res. Clin. Pract. 2017, 2, 1-8. [CrossRef]

139. Jensen, L.D.; Gyllenhaal, C.; Block, K. Circadian angiogenesis. Biomol. Concepts 2014, 5, 245-256. [CrossRef] [PubMed]

140. Busik, J.V.; Tikhonenko, M.; Bhatwadekar, A.; Opreanu, M.; Yakubova, N.; Caballero, S.; Player, D.; Nakagawa, T.; Afzal, A.; Kielczewski, J.; et al. Diabetic retinopathy is associated with bone marrow neuropathy and a depressed peripheral clock. J. Exp. Med. 2009, 206, 2897-2906. [CrossRef] [PubMed]

141. Gomez-Sanchez, E.; Gomez-Sanchez, C.E. The multifaceted mineralocorticoid receptor. Compr. Physiol. 2014, 4, 965-994. [PubMed]

142. Richardson, R.V.; Batchen, E.J.; Denvir, M.A.; Gray, G.A.; Chapman, K.E. Cardiac GR and MR: From Development to Pathology. Trends Endocrinol. Metab. 2016, 27, 35-43. [CrossRef] [PubMed]

143. Garg, R.; Rao, A.D.; Baimas-George, M.; Hurwitz, S.; Foster, C.; Shah, R.V.; Jerosch-Herold, M.; Kwong, R.Y.; Di Carli, M.F.; Adler, G.K. Mineralocorticoid receptor blockade improves coronary microvascular function in individuals with type 2 diabetes. Diabetes 2015, 64, 236-242. [CrossRef] [PubMed]

144. Wilkinson-Berka, J.L.; Tan, G.; Jaworski, K.; Harbig, J.; Miller, A.G. Identification of a retinal aldosterone system and the protective effects of mineralocorticoid receptor antagonism on retinal vascular pathology. Circ. Res. 2009, 104, 124-133. [CrossRef]

145. Felinski, E.A.; Antonetti, D.A. Glucocorticoid regulation of endothelial cell tight junction gene expression: Novel treatments for diabetic retinopathy. Curr. Eye Res. 2005, 30, 949-957. [CrossRef] [PubMed]

146. Ayalasomayajula, S.P.; Ashton, P.; Kompella, U.B. Fluocinolone Inhibits VEGF Expression via Glucocorticoid Receptor in Human Retinal Pigment Epithelial (ARPE-19) Cells and TNF- $\alpha$-Induced Angiogenesis in Chick Chorioallantoic Membrane (CAM). J. Ocul. Pharmacol. Ther. 2009, 25, 97-104. [CrossRef]

147. Taverna, M.J.; Sola, A.; Guyot-Argenton, C.; Pacher, N.; Bruzzo, F.; Slama, G.; Reach, G.; Selam, J.-L. Taq I polymorphism of the vitamin D receptor and risk of severe diabetic retinopathy. Diabetologia 2002, 45, 436-442. [CrossRef]

148. Taverna, M.J.; Selam, J.-L.; Slama, G. Association between a protein polymorphism in the start codon of the vitamin D receptor gene and severe diabetic retinopathy in C-peptide-negative type 1 diabetes. J. Clin. Endocrinol. Metab. 2005, 90, 4803-4808. [CrossRef]

149. Cyganek, K.; Mirkiewicz-Sieradzka, B.; Malecki, M.T.; Wolkow, P.; Skupien, J.; Bobrek, J.; Czogala, M.; Klupa, T.; Sieradzki, J. Clinical risk factors and the role of VDR gene polymorphisms in diabetic retinopathy in Polish type 2 diabetes patients. Acta Diabetol. 2006, 43, 114-119. [CrossRef]

150. Bućan, K.; Ivanisević, M.; Zemunik, T.; Boraska, V.; Skrabić, V.; Vatavuk, Z.; Galetović, D.; Znaor, L. Retinopathy and nephropathy in type 1 diabetic patients-Association with polymorphysms of vitamin D-receptor, TNF, Neuro-D and IL-1 receptor 1 genes. Coll. Antropol. 2009, 33, 99-105.

151. Jia, J.; Ding, H.; Yang, K.; Mao, L.; Zhao, H.; Zhan, Y.; Shen, C. Vitamin D Receptor Genetic Polymorphism Is Significantly Associated with Risk of Type 2 Diabetes Mellitus in Chinese Han Population. Arch. Med. Res. 2015, 46, 572-579. [CrossRef]

(C) 2020 by the authors. Licensee MDPI, Basel, Switzerland. This article is an open access article distributed under the terms and conditions of the Creative Commons Attribution (CC BY) license (http://creativecommons.org/licenses/by/4.0/). 